\title{
Do Lawyers Cause Adversarial Legalism? A Preliminary Inquiry
}

\section{Robert A. Kagan}

Cross-national case studies have indicated that compared to other economically advanced democracies, American methods of policy implementation and dispute resolution are more adversarial and legalistic, shaped by costly court action or the prospect of it. To what extent are lawyers responsible for creating American-style adversarial legalism? This article argues that while adversarial legalism stems primarily from enduring features of American political culture and governmental structure, the legal profession plays a significant independent role in promoting and perpetuating this mode of governance.

Cross-national case studies repeatedly indicate that compared to other economically advanced democracies, American methods of policy implementation and dispute resolution are more adversarial and legalistic, shaped by costly court action or the prospect of it. As a mode of governance, "adversarial legalism" enhances responsiveness to the justice claims of groups and individuals; but it also entails substantial costs, which often frustrate aspirations for justice and social welfare. My purpose in this article, however, is not to analyze the benefits and costs of American adversarial legalism $^{1}$ but to discuss why it arises and persists.

Robert A. Kagan is Professor of Political Science and Law, University of California, Berkeley.

For especially valuable comments, the author is grateful to Peter Schuck, Richard Lempert, Steve Bundy, and participants at the Conference on Legal Cultures and the Legal Profession, Center for the Study of Law and Society, University of California, Berkeley, 7-8 May 1993. The College of Law and the Socio-Legal Center at Ohio State University provided generous research support.

1. For a discussion of some of the costs of adversarial legalism, see Robert A. Kagan, "Adversarial Legalism and American Government," $10 \mathrm{~J}$. Pol'y Analysis \& Mgmt. 309 (1991). There I also briefly discussed possibilities for developing legal instinutions that would preserve 
More specifically, this article addresses the role of American lawyers in creating and perpetuating adversarial legalism. To state the question in a simplistic way, which is closer to the truth?

1. The United States has governmental policies, institutions, and bodies of law that induce or consciously encourage adversarial legalism because lawyers play a large role in formulating and implementing those policies (through litigation and otherwise).

2. Lawyers, insofar as they play a direct role in shaping institutions, policies, and laws, are merely agents-obediently carrying out the preferences of clients, political interest groups, and segments of public opinion; those client, interest group, and popular preferences are what produce adversarial legalism.

In the pages that follow, I argue that while adversarial legalism stems primarily from enduring features of American political culture and governmental structure, the legal profession itself does play a significant independent role in promoting and perpetuating adversarial legal contestation as a prominent feature of governance.

\section{THE DEPENDENT VARIABLE: ADVERSARIAL LEGALISM}

Everywhere in the modern world, it seems, legal control of social and economic life is becoming more intense. ${ }^{2}$ Europeans, observing the growth of constitutional courts, EC regulations, corporate law firms, and inch-thick commercial contracts, speak of the "Americanization" of continental legal life. $^{3}$ During the 1980 s, medical malpractice claims in Canada increased at the same percentage rate as in the United States. ${ }^{4}$ In some fields, such as workers' rights and land use controls, some countries have "more law" and more legal contestation than the United States.

But the United States has a unique "legal style," sufficiently different from that of comparable nations that any talk of "convergence" is quite premature. ${ }^{5}$ That is the message of an accumulating body of detailed case studies that compare governmental responses to particular social problems.

much of the responsiveness associated with adversarial legalism but without generating so much divisiveness, inefficiency, and injustice.

2. Marc Galanter, "Law Abounding: Legalization around the North Atlantic," 55 Mod. L. Rev. 1 (1992).

3. See, e.g., Wolfgang Wiegand, "The Reception of American Law in Europe," 39 Am. J. Comp. L. 229 (1991); David M. Trubek, Yves Dezelay, R. Buchanan, \& J. David, "Global Restructuring and the Law: The Internationalization of Legal Fields" (Working Paper, Global Studies Research Program, University of Wisconsin, Madison, Aug. 1993).

4. D. Dewees, M. Trebilcock, \& P. Coyte, "The Medical Malpractice Crisis: A Comparative Empirical Perspective," 54 Law \& Contemp. Probs. 217 (1991).

5. For example, although the percentage growth of medical malpractice claims in Canada in the 1970s and 1980s paralleled the American increase, in 1986 claims in the United States were 9 times as frequent ( 17 per 100 physicians vs. 1.8 in Canada) and average medical 
Whatever the policy area or social function studied-compensating injured people, regulating pollution, equalizing educational opportunity, deterring malpractice by police, physicians, or product manufacturers-the relevant American legal process tends to be characterized by (1) more complex bodies of legal rules; (2) more formal, adversarial procedures for resolving political and scientific disputes; (3) more costly forms of legal contestation; (4) more punitive legal sanctions; (5) more frequent judicial intervention into administrative decision making; and (6) more political controversy about (and more frequent change of) legal rules and institutions. ${ }^{6}$

Some dimensions of this cluster of legal propensities can be captured in the summary concept "adversarial legalism" — a method of policymaking and dispute resolution characterized by comparatively high degrees of:

a) formal legal contestation-disputants and competing interests invoke legal rights, duties, and procedural requirements, backed by the threat of recourse to judicial review or enforcement; ${ }^{8}$

malpractice insurance premiums were 11 times as high ( $\$ 14,600$ per year vs. $\$ 1,126$ in Canada, in 1990 U.S. dollars). Id.

6. See Joseph Badaracco, Loading the Dice: A Five Country Study of Vinyl Chloride Regulation (Boston: Harvard Business School Press, 1985) ("Badaracco, Loading the Dice"); David Bayley, Forces of Order: Police Behavior in Japan and the United States (Berkeley: University of California Press, 1976); John Braithwaite, To Punish or Persuade: Enforcement of Coal Mine Safety (Albany: SUNY Press, 1985); P. Day \& R. Klein, "The Regulation of Nursing Homes: A Comparative Perspective," 65 Milbank Q. 303 (1987); R. Brickman, S. Jasanoff, \& T. Ilgen, Controlling Chemicals: The Politics of Regulation in Europe and the United States (Ithaca, N.Y.: Cornell University Press, 1985) ("Brickman et al., Controlling Chemicals"); Sheila Jasanoff, Risk Management and Political Culture (New York: Russell Sage Foundation, 1986); Steven Kelman, Regulating America, Regulating Sweden: A Comparative Study of Occupational Safety and Healch Policy (Cambridge, Mass.: MIT Press, 1981); David Kirp, Doing Good by Doing Little: Race and Schooling in Britain (Berkeley: University of California Press, 1979); id., "Professionalization as a Policy Choice: British Special Education in Comparative Perspective," 34 World Politics 137 (1982); John Langbein, "The German Advantage in Civil Procedure," 52 U. Chi. L. Rev. 823 (1985); Lennart J. Lundqvist, The Hare and the Tortoise: Clean Air Policies in the United States and Sweden (Ann Arbor: University of Michigan Press, 1980); Lois Quam et al., "Medical Malpractice in Perspective," 294 Brit. Med. J. 1529, 1597 (1987); Gary Schwartz, "Product Liability and Medical Malpractice in Comparative Context," in Peter Huber \& R. Litan, eds., The Liability Maze (Washington, D.C.: Brookings Institution, 1991); Takao Tanase, "The Management of Disputes: Automobile Accident Compensation in Japan," 24 Law \& Soc'y Rev. 651 (1990); David Vogel, National Styles of Regulation: Environmental Policy in Great Britain and the United States (Ithaca, N.Y.: Cornell University Press, 1986) ("Vogel, National Styles"); Derek Bok, "Reflections on the Distinctive Character of American Labor Laws," 84 Harv. L. Rev. 1461 (1971); Robert J. Flanagan, Labor Relations and the Litigation Explosion (Washington, D.C.: Brookings Institution, 1987); Mary Ann Glendon, Abortion and Divorce in Western Law (Cambridge, Mass.: Harvard University Press, 1987); Robert Reich, "Bailout: A Comparative Study in Law and Industrial Structure," 2 Yale J. Reg. 163 (1985); Harvey Teff, "Drug Approval in England and the United States," 33 Am. J. Comp. L. 567 (1985).

7. See Kagan, $10 \mathrm{~J}$. Pol'y Analysis \& Mgmt.

8. This does not mean, of course, that Americans always define their problems in legal terms and always seek legal redress. Clearly, they don't. Thomas B. Metzloff, "Researching Litigation: The Medical Malpractice Example," 51 Law \& Contemp. Probs. 199 (1988); Michael J. Saks, "Do We Really Know Anything about the Behavior of the Tort Litigation System-And Why Not?" 140 Pa. L. Rev. 1147 (1992); Robert A. Kagan, "The Routinization of Debt Collection: An Essay on Social Change and Conflict in the Courts," 18 Law \& Soc'y 
b) litigant activism - the gathering and submission of evidence and the articulation of claims is dominated or profoundly influenced by disputing parties or interests, acting primarily through lawyers;

c) substantive uncertainty - official decisions, in relative or comparative terms, are variable, unpredictable, and reversible; hence adversarial advocacy can have a substantial impact.

Table 1 displays the first two variables schematically. As the table suggests, adversarial legalism differs first of all from informal decision processes-which range from mediation of individual disputes, to reliance on expert professional judgment, to judgment by political authorities. Second, in its reliance on litigant activism, adversarial legalism also differs from decision making that is legally formal but more hierarchical, that is, in which an authoritative legal official or body, accountable to bureaucratically organized superiors, controls the process and the standards for decision. ${ }^{9}$ Thus in western European courts, judges-not attorneys for the parties-dominate fact gathering and selection of expert witnesses. ${ }^{10}$ More broadly, American reliance on tort law for compensating victims of highway, medical, and product-related accidents is more adversarial than European methods of responding to accident victims, which operate primarily through hierarchically organized health care and benefit-payment bureaucracies.

\section{TABLE 1}

Modes of Policymaking and Dispute Resolution

\section{Informal to Formal}

Hierarchical

to

Party-influenced

\begin{tabular}{|c|l|}
\hline $\begin{array}{c}\text { Expert or } \\
\text { political }\end{array}$ & $\begin{array}{l}\text { Bureaucratic } \\
\text { legalism }\end{array}$ \\
\hline $\begin{array}{c}\text { Negotiation/ } \\
\text { mediation }\end{array}$ & $\begin{array}{c}\text { Adversarial } \\
\text { legalism }\end{array}$ \\
\hline
\end{tabular}

Rev. 323 (1984). And there is enormous variation in rates of recourse to legal action across American subcultures, regulatory programs, and types of grievance. R. Miller \& A. Sarat, "Grievances, Claims and Disputes: Assessing the Adversary Culture," 15 Law $\mathcal{B}$ Soc'y Rev. 525 (1980-81); David M. Engel, "The Oven Bird's Song: Insiders, Outsiders, and Personal Injuries in an American Community," 18 Law \& Soc'y Rev. 551 (1984); David Caplovitz, Consumers in Trouble: A Study of Debtors in Default (New York: Free Press, 1974); Robert A. Kagan, "Understanding Regulatory Enforcement," 11 Law \& Pol'y 89 (1989). The point is that in comparative, cross-national terms, adversarial legalism is more prevalent in the United States.

9. The typology I suggest draws heavily on the one developed by Mirjan Damaska, The Faces of Justice and State Authority: A Comparative Approach to the Legal Process (New Haven, Conn.: Yale University Press, 1986) ("Damaska, Faces of Justice"), and is also indebted to Jerry L. Mashaw, Bureaucratic Justice: Managing Social Security Disability Claims (New Haven, Conn.: Yale University Press, 1983); J. Thibaut \& Laurens Walker, "A Theory of Procedure," 66 Cal. L. Rev. 541 (1978); and Kirp, 34 World Politics 137 (1982).

10. Langbein, 52 U. Chi. L. Rev. (cited in note 6). 
Even when compared to the British "adversarial system" from which it descended, American methods of adjudication are far more party-influenced, less hierarchically controlled, and consequently less predictable. American judges are more diverse, more political, more autonomous than British judges, and their decisions are less uniform. ${ }^{11}$ Law is treated as more malleable, open to parties' novel legal and policy arguments. In civil cases, lay jurors still play a large and normatively important role in the United States, which magnifies the importance of skillful legal advocacy and reduces legal certainty. ${ }^{12}$

Similarly, compared to European democracies, regulatory decision making in the United States entails many more legal formalities-public notice and comment, open hearings, restrictions on ex parte and other informal contacts, high evidentiary and scientific standards, mandatory official "findings" and responses to interest group arguments-most of which are designed to enhance interest group participation and review by courts. Concomitantly, hierarchical authority in American agencies is weaker than in European regulatory bodies, where lawyers rarely participate, and appeals to the courts are even rarer. ${ }^{13}$

Adversarial legalism is not uniformly distributed throughout the American legal order. Some policy arenas and administrative systems are rather free of litigation and the threat of it. Some communities, subcultures, and industries disparage and eschew legal contestation. ${ }^{14}$ Many kinds of problems and losses are dealt with by private or public insurance, not by litigation. ${ }^{15}$ Even in social arenas in which the processes of adversarial legalism often are invoked, full-scale legal contestation usually does not occur. In a system pervaded by adversarial legalism, the costs and delays associated with formal litigation impel most disputants to negotiate an informal plea bargain or settlement, even if it means abandoning valid claims or defenses. ${ }^{16}$ Thus

11. P. S. Atiyah \& R. Summers, Form and Substance in Anglo-American Law: A Comparative Study of Legal Reasoning, Legal Theory, and Legal Institutions (Oxford: Clarendon Press, 1987) ("Atiyah \& Summers, Form and Substance").

12. Several surveys and experiments have shown that attorneys and insurance claims managers assign widely different settlement values to civil cases. Marc Galanter, "The Quality of Settlements," 1988 J. Dispute Resolution 55; Gerald Williams, Legal Negotiation and Settlement 6, 111-14 (St. Paul, Minn.: West Publishing Co., 1983); Douglas B. Rosenthal, Lawyer and Client: Who's in Charge? 202-7 (New York: Russell Sage Foundation, 1974); Saks, 140 Pa. L. Rev. 1215, 1223.

13. Badaracco, Loading the Dice; Brickman et al., Controlling Chemicals; Vogel, National Styles; Teff, 33 Am. J. Comp. L. (all cited in note 6).

14. Carol J. Greenhouse, Praying for Justice: Faith, Order and Community in an American Town (Ithaca, N.Y.: Cornell University Press, 1986); Robert C. Ellickson, "Of Coase and Cattle: Dispute Resolution among Neighbors in Shasta County," 38 Stan. L. Rev. 623 (1986); Stewart Macaulay, "Non-contractual Relations in Business: A Preliminary Study," 28 Am. Soc. Rev. 55 (1963). See also references cited in note 8.

15. See Kagan, 18 Law \& Soc'y Rev. (cited in note 9).

16. Malcolm M. Feeley, The Process Is the Punishment: Handling Cases in a Lower Criminal Court (New York: Russell Sage Foundation, 1979); Stewart Macaulay, "Lawyers and Consumer Protection Laws," 14 Law \& Soc'y Rev. 115 (1979). 
the impact and importance of adversarial legalism cannot be measured by litigation or adjudication rates alone.

By the same token, the positive effects of adversarial legalism often stem from the costs and publicity that it merely threatens to unleash. Even if only a minority of injured persons bring suit, the structures of adversarial legalism can prevent malpractice by physicians, polluters, police, and politicians. Simply by empowering citizens to challenge the plans and assumptions of biased or incompetent officials, adversarial legalism can make the insurance adjustor, the prosecutor, the welfare office, and the zoning board attend more carefully to the evidence and the equities of individual cases.

Consequently, in seeking to better define, measure, and explain adversarial legalism, it is helpful to regard the concept as encompassing both (1) a set of legal structures, institutions, and rules that facilitate or encourage adversarial, party-dominated legal contestation as a mode of policy implementation and dispute resolution; and (2) the day-to-day practice of adversarial legal contestation.

\section{TWO COMPETING HYPOTHESES}

\section{A. Thesis: Lawyers as Cause of Adversarial Legalism}

When I told my father that I was interested in why the United States had more adversarial legalism than other countries, he said, "It's simple. Because we have so many lawyers!" A stranger sitting beside me on an airplane offered a similar explanation: "Because there's so much money in it!" Sophisticated sociolegal scholars, on the other hand, tend to believe that the salience of lawyers and lawyering in the United States is a consequence rather than a cause of adversarial legalism. Nevertheless, a plausible "supplyside" argument can be constructed.

After all, the American legal profession, while it may no longer constitute the quasi-aristocracy that Tocqueville observed, constitutes a large, profitable industry, ${ }^{17}$ composed of particularly intelligent, articulate, ambitious, wealthy, and well-connected people. Lawyers and legally trained politicians outnumber representatives of all other occupations and professions at the commanding heights of American government-chief executives, ${ }^{18}$ leg-

17. Richard H. Sander, "Elevating the Debate on Lawyers and Economic Growth," 17 Law \& Soc. Inquiry 659, 665 (1992), calculates that the United States currently spends about $\$ 100$ billion per year on legal services (up from $\$ 30$ billion, measured in 1992 dollars, in 1970).

18. In the 1980 s, more than half of all state governors were lawyers, and more than half of all U.S. presidents have been lawyers. Mark C. Miller, "Lawyers and American Politics: An Interdisciplinary Perspective" (presented at Law \& Society Association annual meeting, 1992). 
islatures, ${ }^{19}$ legislative staffs, administrative agencies, ${ }^{20}$ the judiciary, law reform commissions. Professions, we are often told, typically seek to create and preserve economic advantages and influence for their members. ${ }^{21}$ Hence, if lawyers make the laws, promulgate the regulations, and decide the court cases, one would expect them to perpetuate legal forms and valuesincluding ready access to courts, due process norms, strong rights to legal representation, and a significant policymaking and oversight role for the judiciary-that preserve lawyers' influence on legal reform and implementation. ${ }^{22}$

Their reasons for doing so are not necessarily venal. Lawyers' ideals as well as lawyers' interests may incline them to preserve and extend adversarial legalism. Lawyers, one would imagine, have a tendency to advocate methods of governance and dispute resolution with which they are professionally familiar. ${ }^{23}$ Typically, one suspects, they believe that the adversarial legal methods they studied in law school actually further the public interest. It seems likely, therefore, that the prevalence of lawyers in high placeslobbying firms, legislatures, commissions, legislative and administrative staffs-generates steady pressures to preserve and expand the realm of legal rights and remedies, due process protections, and opportunities for challenging the legal basis for governmental action.

\section{B. Antithesis: Lawyers as Consequence of Adversarial Legalism}

Despite the plausibility of the lawyers-as-cause argument, there are reasons to think that the contrasting hypothesis-that the salience of lawyers and lawyering in America is a consequence rather than a cause of adversarial legalism-is more powerful. The lawyers-as-consequence thesis reflects the argument that adversarial legalism arises primarily from the confluence of two conflicting features of the American political system:

19. In the 1980 s, slightly more than $60 \%$ of U.S. senators and $44 \%$ of U.S. House members were lawyers (somewhat fewer than in 1955, 1965, and 1975). Id. at 6.

20. A majority of the heads of departments in President Clinton's cabinet are lawyers. More than two-thirds of presidential appointees to head the EPA and to serve on the EEOC, FCC, FTC, NLRB, and SEC in recent decades have been lawyers. Id. at 3.

21. Richard L. Abel, American Lauyers (New York: Oxford University Press, 1989); Andrew Abbott, The System of Professions: An Essay on the Division of Expert Labor (Chicago: University of Chicago Press, 1988).

22. Ronen Shamir, "Professionalism and Monopoly of Expertise: Lawyers and Administrative Law, 1933-1937," 27 Law \& Soc'y Rev. 361 (1993).

23. Nelson W. Polsby, "The Social Composition of Congress," in U. Thaysen et al., eds., The U.S. Congress and the German Bundestag: Comparisons of Democratic Processes 114 (Boulder, Col.: Westview Press, 1990): "The occupational culture of Congress is dominated by lawyers' ways and lawyers' jargon. Committees are organized to elicit information by 'holding hearings' in which 'witnesses' 'testify' and are examined 'on the record' by questions from members and staff. At least one high-ranking staff member, and usually more than one, is a lawyer and is known as 'counsel' to the committee." 
1. A political culture that in recent decades has demanded increasingly comprehensive governmental protections from harm, injustice, and environmental dangers-and hence a more powerful, activist central government; and, paradoxically,

2. Governmental structures based on mistrust of concentrated power-and that hence fragment governmental authority and check its exercise by means of privately initiated lawsuits, appeals, and judicial review. 24

To summarize the argument briefly, beginning in the 1960s, American reform movements and political leaders sought and won greatly expanded legal protections from economic loss, discrimination, and environmental degradation, as well as from harmful products and processes. The form these expanded protections took, however, was molded by structure of the government that enacted them. That structure typically is described as pluralistic, or even as hyper-pluralistic ${ }^{25}$ - governmental authority is fragmented among federal, state and local governments, across the branches of government at each level, and within political parties and Congress.

Thus when the political movements of the 1960s and 1970s demanded greater governmental protections and entitlements, they confronted structural limitations on governmental activism. Authority to articulate and enforce the new, ambitious governmental programs and legal norms could not be entrusted to large, centralized, national bureaucracies or corporatist bodies, such as those that characterize many European states. Instead, the enhanced governmental powers to implement new policies were dispersed among a welter of governmental bodies and private organizations.

But with authority dispersed and hierarchical control limited, how could coordination and accountability in policy implementation be assured? The mechanisms chosen were those of adversarial legalism-procedurally complex statutory rules, privately enforceable legal rights, and a powerful,

\section{FIGURE 1}

\section{Lawyers as Consequence of Adversarial Legalism}

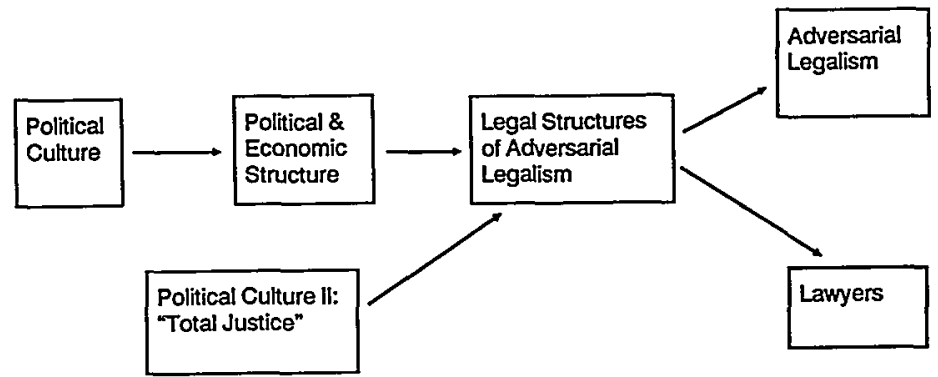

24. Kagan, $10 \mathrm{~J}$. Policy Analysis $8 \mathrm{Mgmt}$. (cired in note 1 ).

25. Robert L. Lineberry, Government in America: People, Politics, and Policy 52-60 (2d ed. Boston: Little, Brown, 1983). 
politically responsive judiciary-all of which facilitate legal challenges to official decisions by private interest groups and ordinary citizens. And in a system of governance that seeks accountability through legal challenge rather than by hierarchical review, lawyers are bound to be called into play.

Figure 1 sketches the basic components of the lawyers-as-consequence thesis. The basic building blocks, described a bit more fully, are as follows:

\section{Political Culture}

The taproot of adversarial legalism is the "liberalism" that has dominated American political culture since the nation's birth. ${ }^{26}$ American political liberalism has always emphasized the primacy of individual liberties and rights vis-à-vis governmental control. Governmental power, in the liberal vision, must be limited and restrained by law, invoked and applied by citizens. American political culture has also harbored a turbulent "populist" strain, deeply mistrustful of accumulations of economic power and quick to believe that government officials will engage in self-dealing or succumb to corruption by business interests. ${ }^{27}$

\section{Political and Economic Structure}

These basic political attitudes are embodied in political and economic structures designed to limit and fragment power, both public and private. The U.S. Constitution splintered governmental authority among separate "branches," compelled the national government to share or concede much governing power to the states, and added a judicially enforceable Bill of Rights. In this constitutional structure, courts were drawn into the role of umpires for conflicts among governmental branches and geographical jurisdictions as well as conflicts between state and citizen; hence Tocqueville's observation that in 19th-century America, important political questions often were transmuted into judicial questions. ${ }^{28}$ With a tradition of limited as well as decentralized government, in the 19th century America was not a state dominated by legislatures and bureaucrats but, as Stephen Skowronek

26. Louis Hartz, The Liberal Tradition in America: An Interpretation of American Political Thought since the Revolution (New York: Harcourt, Brace \& World, 1955). Some scholars have argued that Hartz and others have neglected the extent to which profoundly illiberal political ideas, such as nativism, sexism, and racism, have contended with liberalism in American political culture and law. See, e.g., Rogers M. Smith, "Beyond Tocqueville, Myrdal, and Hartz: The Multiple Traditions in America," 87 Am. Pol. Sci. Rev. 549 (1993). Still, viewed comparatively, liberalism is what best distinguishes the American political culture from that of most other economically advanced democracies.

27. Lawrence Goodwyn, The Populist Moment: A Short History of the Agrarian Revolt in America (New York: Oxford University Press, 1978). 1945).

28. Alexis de Tocqueville, 1 Democracy in America 290 (1835; New York: Vintage Books, 
put it, "a state of [political] parties and courts."29 State legislatures that met for limited terms and were slow to act further encouraged judges to become active policymakers. ${ }^{30}$ And where courts are politically potent, lawyers almost inevitably thrive.

By European standards, America's national administrative bureaucracy was slow to develop. Bureaucratization was retarded by the federal structure and by a constitution that, as interpreted by the judiciary, limited the central government's authority over state and local affairs. With governmental growth inhibited, American economic life, compared to that of European society, was more dominated by private, market-based social and economic relationships. These were policed primarily by judicially made rules, enforceable by litigation, again exalting the role and prevalence of lawyers in legal development and the management of disputes.

Similarly, partly because the polity mistrusted concentrated economic power, American capitalism has always been far more fragmented and competitive than in Europe and Japan, where industrial and financial structure is dominated by cartels, powerful industrial associations, central banks, and government-owned companies. ${ }^{31}$ Hence in America, conflict among business firms could less easily be contained and resolved by hierarchical processes; rather, regulation of commercial relations and the consequences of business failure were left more fully to the realms of contract law, private litigation, and lawyering.

\section{Legal Structures of Adversarial Legalism}

If you mistrust concentrated power, care about individual rights, and believe in private ordering, you might well prefer legal institutions and rules that enable citizens to challenge official power in court. And thus America long has prized what might be called the "legal structures of adversarial legalism"-trial by jury and a politically selected judiciary (both of which maximize local responsiveness while reducing legal uniformity, certainty,

29. Stephen Skowronek, Building a New American State: The Expansion of National Administrative Capacities, 1877-1920 (New York: Cambridge University Press, 1982). Judicial power, too, was fragmented, rather than centralized and hierarchically ordered. American trial court judges shared power with locally selected juries. Most judges were selected by countylevel political and electoral processes-in sharp contrast to European methods, which entailed lengthy apprenticeships in a centrally controlled, professionalized, judicial hierarchy. American judges thus were often former politicians or politically active attorneys, inclined not toward a formalistic but toward a pragmatic, problem-solving approach to the law. And in such a fluid, decentralized, somewhat unpredictable court system, the skills of private advocates could be particularly influential, enhancing lawyers' role in shaping the law and in resolving and forfending disputes.

30. Morton Horwitz, The Transformation of American Law, 1780-1860 (Cambridge, Mass.: Harvard University Press, 1977) ("Horwitz, Transformation of American Law").

31. Mark Roe, "A Political Theory of American Corporate Finance," 91 Colum. L. Rev. 10 (1991); Lester Thurow, "Communitarian vs. Individualistic Capitalism," 2 Responsive Community, Fall 1992, at 24. 
and central control); methods of adjudication that rely primarily on lawyers, rather than judges, to develop and manage the presentation of evidence and arguments; and legal doctrines and rules that encourage action by and access to courts. Among the latter are those that authorize judicial review and reversal of governmental decisions on both statutory and constitutional grounds, that permit contingency fees for plaintiffs' lawyers, and that do not require litigants who lose in court to reimburse the winners for their lawyers' bills. These "structures of adversarial legalism" facilitate, but do not necessarily lead to, high levels of litigation or what we might call "adversarial legalism in practice."

\section{Political Culture II: "Total Justice"}

Although detailed studies are hard to find, the historical legacy discussed thus far-political liberalism and populism, power-fragmenting political and economic structures, institutions and legal traditions conducive to litigation-suggests that at almost any point the United States would have had more "adversarial legalism in practice" than economically advanced European countries. Nevertheless, the adversarial legalism that has pervaded the United States in the past few decades differs both in intensity and extensiveness, from that of the late 19th and the first half of the 20th century. ${ }^{32}$

In the early 1960s, the decisions of American administrative agencies, school boards, police officers, prison administrators, and zoning boards were not challenged in court nearly as often as they have been in the past 20 years. ${ }^{33}$ Litigation was not an omnipresent consideration in electoral redistricting, the practice of medicine, corporate acquisitions, and the formulation of regulatory rules. Both criminal and civil trials were far shorter. Litigation between business enterprises was less common. ${ }^{34}$ Between 1960

32. Kagan, $10 \mathrm{~J}$. Policy Analysis \& Mgmt. (cited in note 1).

33. Peter Schuck, Suing Government: Citizen Remedies for Official Wrongs 199-202 (New Haven, Conn.: Yale University Press, 1983) ("Schuck, Suing Government"), uses federal court statistics on "civil rights cases" to illustrate the increase in suits against government. These increased from 280 filings in 1960 to about 27,000 in 1980. Since 1976, Schuck notes, almost one of three private federal questions filed in U.S. district courts has been a civil rights action against a state or federal official. Estimates based on federal court statistics indicate that federal courts of appeal in 1980 decided some 2,000 cases involving seriously contested constitutional issues, compared to perhaps 300 in 1960 . Robert A. Kagan, "Constitutional Litigation in the United States," in R. Rogowski \& T. Gawron, eds., Constitutional Courts in Comparison (Gummarsbach: Theodor Heuss Academie, 1987). The volume and rate of state appellate and federal court cases involving public schools, roughly stable from 1920 through 1960, doubled in the 1967-81 period. D. Tyack \& A. Benavot, "Courts and Public Schools: Education Litigation in Historical Perspective," 19 Law $\mathcal{E}$ Soc'y Rev. 339, 348 (1985).

34. Marc Galanter \& Joel Rogers, "The Transformation of American Business Disputing? Some Preliminary Observations" (delivered at Law \& Society Association annual meeting, 1988); T. Dungworth, M. Galanter, \& J. Rogers, "Corporations in Court: Recent Trends in American Business Litigation" (delivered at Law \& Society Association annual meeting, 
and 1987, expenditures on lawyers grew sixfold, from $\$ 9$ billion annually to $\$ 54$ billion (in constant 1983 dollars), almost tripling the share of GNP consumed by legal services. ${ }^{35}$

At the most immediate level, these changes stemmed from an explosion of new legal rules and institutions-the Warren Court's "due process revolution"; sweeping changes in tort law; extension of the right to counsel and creation of public defender offices, federally funded legal services offices, and public interest law firms; "judicialization" of administrative rulemaking; institutionalization of the judicially reviewable environmental impact statement; and most important, a flood of ambitious regulatory statutes, federal and state, establishing new rights and obligations concerning pollution control, consumer protection, and discrimination based on race, gender, age, and disability. These regulatory statutes, moreover, differed from those enacted during the Progressive Era and the New Deal in their greater complexity and specificity, legalistic approach to enforcement, and other invitations to adversarial legalism. ${ }^{36}$

But why was there such an outpouring of new law? Something had been added to the inherited political system noted earlier. In the mid-1960s, the United States experienced what Samuel Huntington labels a period of "creedal passion." During such recurrent episodes, he argues, Americans grow impatient with the incremental processes of "normal politics"; they turn to demonstration and protest, decrying the gap between liberal, egalitarian ideals and current institutional practices. 37 Thus in the 1960s and early 1970s, the political techniques and moral urgency of the civil rights movement, with its demands for legal action against racial discrimination, spilled over into the environmental, consumer protection, and feminist movements. Congress and the Supreme Court responded by promulgating a plethora of new legal rights and obligations.

Some observers, moreover, see the legal changes of recent decades as reflecting not merely a periodic burst of idealism but a more enduring change in American political culture. To Aaron Wildavsky, they reflect the growing strength of the egalitarian strain in American political culture, critical of inequalities of wealth and power, eager for governmental action against the technological risks and economic vulnerabilities associated with

1990); William Nelson, "Contract Litigation and the Elite Bar in New York City, 1960-1980," 39 Emory L. Rev. 441, 446 (1990); Ross Cheit, "Corporate Ambulance Chasers: The Charmed Life of Business Litigation," 11 Stud. L., Pol. \& Soc'y 119 (1991).

35. Richard H. Sander \& E. Douglass Williams, "Why Are There So Many Lawyers? Perspectives on a Turbulent Market," 14 Law \& Soc. Inquiry 431, 434-35 (1989).

36. Bruce Ackerman \& W. Hassler, Clean Coal/Dirty Air (New Haven, Conn.: Yale University Press, 1981); E. Bardach \& R. Kagan, Going by the Book: The Problem of Regulatory Unreasonableness (A Twentieth Century Fund Report) (Philadelphia: Temple University Press, 1982).

37. Samuel Huntington, American Politics: The Promise of Disharmony (Cambridge, Mass.: Belknap Press, 1981). 
capitalism. ${ }^{38}$ Lawrence Friedman, surveying American culture, points to rising expectations of "total justice"39-the notion that modern, technologically and organizationally sophisticated societies can (and hence should) compensate victims of unfair treatment, personal injury, unexpected economic loss and health care costs, and provide regulatory protections against many sources of harm. 40

\section{Total Justice Meets Fragmented Government}

Increasing popular expectations of "total justice," however, are not unique to the United States. In the post-World War II period, increasingly rich European democracies, too, have enacted a flood of new laws that expand governmental protections against misfortune, environmental degradation, and unfair treatment. But they have done so without also creating American levels of adversarial legalism. The difference stems primarily from the European democracies' more hierarchical or corporatist political structures and traditions. There, national governmental bureaucracies and corporatist bodies implement ambitious regulations and welfare-state entitlement programs without much interference from courts and lawyers.

In the United States, in contrast, demands for "total justice" and regulatory protections have been filtered through a political culture that mistrusts "big government" and resists high taxes. ${ }^{41}$ In a political system that lacks strong national law enforcement, regulatory, medical care and welfare bureaucracies, the satisfaction of demands for "total justice" necessarily has been left in large measure to state and local judges and governmental agencies, even for the implementation of federally enacted programs and policies. Without the capacity for exercising centralized, "top-down" control over local police officers, environmental inspectors, school districts, and businesses, legislators and high courts have granted ordinary citizens and

38. Aaron Wildavsky, "A World of Difference-The Public Philosophies and Political Behaviors of Rival American Cultures," in Anthony King, ed., The New American Political System (2d version. Washington, D.C.: AEI Press, 1990); D. Polisar \& A. Wildavsky, "From Individual Blame to System Blame: A Cultural Analysis of Historical Change in the Law of Torts," 1 J. Pol'y Hist. 122 (1989).

39. Lawrence M. Friedman, Total Justice (New York: Russell Sage Foundation, 1985) ("Friedman, Total Justice").

40. The general expectation of compensation that Friedman discerns does not mean that most Americans expect to be compensated for all harms, regardless of fault. Surveys show that at least for injuries arising in contexts other than motor vehicle accidents, most citizens do not automatically blame others or initiate lawsuits. Deborah Hensler et al., Compensation for Accidental Injuries in the United States (Santa Monica, Cal.: RAND Institute for Civil Justice, 1991). Still, there is little doubt that citizens, on balance, now expect and even demand governmental or legal remedies for kinds of harms or losses (from natural disasters to bank failures to discrimination) that their grandparents would have accepted fatalistically.

41. Seymour Martin Lipset, "A Weak Concept of the Common Good," 1 Responsive Community, Fall 1991, at 81, and id., Continental Divide: The Values and Institutions of the United States and Canada (New York: Routledge, 1990). 
advocacy groups the right to haul errant officials and corporations into court. Lawyers and adversarial legalism thus substitute for hierarchical bureaucratic and political accountability mechanisms.

Similarly, even as the reach and power of the federal government grew, an electorate mistrustful of government and political leaders mistrustful of each other increased the fragmentation of authority-between a president and Congress of different parties, within a subcommittee-dominated Congress, and perhaps most important, within political parties. ${ }^{42} \mathrm{~A}$ Congress mistrustful of the president enacts more detailed statutes, so that courts can be called into play to monitor the executive branch. Fragmentation of power creates more pressure points for local, ideological, and economic interest groups. Interest groups push for laws that enable their constituents to challenge unsympathetic administrators and recalcitrant businesses in court. ${ }^{43}$ Lawyers and adversarial legalism thus are called into being by political interests as tools for maintaining influence over the implementation of more activist government policy.

Structural features of American courts and legislatures have long made American law more uncertain and malleable than law in Great Britain (and most European countries). The United States is almost unique in committing civil cases to lay jurors and in staffing its courts with politically selected, relatively untrained judges - which in turn encourages the free play of judges' personal attitudes, prejudices, and visions of justice. In the sphere of statutory law, weak political party control over individual legislators and committee chairs often leads to substantively incoherent statutory compromises and last-minute amendments. ${ }^{44}$ In recent decades, however, legal uncertainty seems to have increased. Pressured to respond to popular demands for more ambitious, socially transformative policies, political divisions in American courts and legislatures seem have become sharper. Since the 1960 s, high courts have been riven by higher dissent rates. ${ }^{45}$ Political struggles over the composition of the judiciary have intensified, and changes in judicial personnel have led to rapid doctrinal shifts. Congressional statutes have become longer, more complex, and often hopelessly confusing, as each interest group is awarded a provision acknowledging its concerns and key substantive terms are often left undefined. ${ }^{46}$ When legislation is unclear

42. Stephen Griffin, "Bringing the State into Constitutional Theory: Public Authority and the Constitution," 16 Law \& Soc. Inquiry 659, 701-9 (1991), provides a review and compelling synthesis of the literature on declining popular trust of government and structural impediments to governmental action.

43. Terry Moe, "The Politics of the Bureaucratic State," in J. Chubb \& P. Peterson, eds, Can the Government Govern? (Washington, D.C.: Brookings Institution, 1989).

44. Atiyah \& Summers, Form and Substance (cited in note 11).

45. L. Friedman, R. Kagan, B. Cartwright \& S. Wheeler, "State Supreme Courts: A Century of Style and Citation," 33 Stan. L. Rev. 773 (1981).

46. Peter Schuck, "Legal Complexity: Some Causes, Consequences, and Cures," 42 Duke L.J. 1, 27-30 (1992). 
and court decisions unpredictable or malleable, then disputants have more incentive to hire lawyers and seek to reshape the law to their own ends.

As noted earlier, American business and corporate finance long have been more decentralized and competitive than their European counterparts, ${ }^{47}$ as has American labor. ${ }^{48}$ Similarly, American pension, insurance, and health care systems are left far more fully to the private sector and are more fragmented and competitive. In recent decades, however, this inherited economic structure has been subjected to greatly intensified competitive pressures. And that has meant that in the United States, in contrast to Germany and Japan, there have been no strong industry associations, labor federations, bank holding companies, or governmental ministries that could help contain the resulting financial difficulties and power struggles. ${ }^{49}$ In the more fragmented U.S. economy, short-term market relationships and the risk of opportunism have become more pervasive. ${ }^{50}$ Thus lengthy contracts, legalistic government regulation, and litigation help fill the need for governance, enhancing demand for lawyers.

In sum, the lawyers-as-consequence thesis holds that structural features of the American political and economic system create a demand for lawyering. The demand arises independent of, regardless of, the interests and views of the legal profession. Deeply rooted economic and political attitudes and structures are the locomotive of adversarial legalism; lawyers seem to have their hand on the throttle, but they are basically just along for the ride"mouthpieces" and "hired guns" serving the interests of others. From this perspective, if all American lawyers were suddenly incapacitated by a disease that struck only the legally trained (lawpox? weasels?), new lawyers, or nonlawyers who did just about the same things, would soon be called into action by politicians, lobbyists, judges, and clients of all kinds, and there would be little change in the incidence or intensity of adversarial legalism.

\section{SYNTHESIS: LAWYERS AS SECONDARY CAUSE OF ADVERSARIAL LEGALISM}

How can we assess the relative power of the lawyers-as-cause versus the lawyers-as-consequence hypothesis? Some research suggests that American

47. Roe, 91 Colum. L. Rev. 10, and Thurow, 2 Responsive Community (both cited in note 31); but see John C. Coffee, Jr., "Liquidity versus Control: The Institutional Investor as Corporate Monitor," 91 Colum. L. Rev. 1277 (1991).

48. Joel Rogers, "Divide and Conquer: Further 'Reflections on the Distinctive Character of American Labor Laws," 1990 Wis. L. Rev. 1; Robert A. Kagan, "How Much Does Law Matter? Labor Law, Competition, and Waterfront Labor Relations in Rotterdam and U.S. Ports," 24 Law 8 Soc'y Rev. 35 (1990). 6).

49. For an interesting comparative case study, see Reich, 2 Yale J. Reg. 163 (cited in note

50. Ronald J. Gilson, "How Many Lawyers Does It Take to Change an Economy?" 17 Law \& Soc. Inquiry 637, 638 (1992). 
lawyers, as such, do not play a major independent role in shaping policy. Lawyers for the powerful primarily seem to be "conduits";51 they do their clients bidding, share their clients' political attitudes, and exercise relatively little independent influence on corporate clients' goals. 52 In explaining the behavior of legislators, political scientists generally refer to variables such as political party, constituency characteristics, committee specialization, and the like; they do not seem to regard legislators' legal training or experience, or lack of it, as important. There is little empirical evidence that lawtrained legislators, staffers, or top agency officials-whose very numbers suggest internal political diversity-differ systematically from nonlawyer colleagues. ${ }^{53}$ Similarly, the diversity of interests among judges and private lawyers means that some are at the forefront in pushing for reforms that seek to reduce adversarial legalism. ${ }^{54}$

Nevertheless, the available empirical evidence is skimpy and only indirectly relevant to the question at hand. Little if any research has systematically examined lawyers' roles in extending adversarial legalism. This article's first conclusion, therefore, is that social scientists really haven't established much about the issue.

Second, even if, as the lawyers-as-consequence thesis holds, structural features of American government and broader dispositions to mistrust government are the primary causes of adversarial legalism, that does not mean that the legal profession and the legal culture it continuously recreates play no causal role.

Consider, for example, the relationship between federalism and adversarial legalism. The federal structure of American government means that top officials in Washington, D.C., lack direct supervisory powers over local governmental officials who violate national norms and policies; they can neither fire them nor offer them promotions for future good behavior. That is one reason why proponents of nationwide pollution control norms lobbied for federal statutes that give advocacy groups the right to bring lawsuits

51. R. Kagan \& R. Rosen, "The Social Significance of Large Firm Law Practice," 37 Stan. L. Rev. 399 (1985).

52. John P. Heinz, "The Power of Lawyers," 17 Ga. L. Rev. 891 (1983); Robert Nelson, Partners with Power (Berkeley: University of California Press, 1988); Robert Nelson \& John P. Heinz, "Lawyers and the Structure of Influence in Washington," 22 Law \& Soc'y Rev. 237 (1988).

53. One noteworthy exception is Jerry Mashaw and Daniel Harfe's study of the National Highway Safety Administration (NHTSA). There, top legal officials regularly clashed with engineers concerning regulatory strategy. Lawyers tended to emphasize recalls rather than mandatory design standards. Lawyers, moreover, clashed with engineers as to whether recalls were warranted in particular cases. To the lawyers, a primary consideration was whether they could "win in court." Jerry Mashaw \& Daniel Harfst, The Struggle for Auto Safety 183 (Cambridge, Mass.: Harvard University Press, 1990). See also Robert A. Katzmann, Regulatory Bureaucracy: The Federal Trade Commission and Antitrust Policy (Cambridge, Mass.: MIT Press, 1980).

54. Laura Nader, "The ADR Explosion-The Implications of Rhetoric in Legal Reform," 8 Windsor Y.B. Access to Just. 269 (1988). 
against state and local officials responsible for implementing federal environmental laws. That is why proponents of nationwide controls on police behavior sought Supreme Court rulings requiring local judges to suppress evidence obtained in violation of federally elaborated constitutional norms and why the Court insisted that states provide lawyers to indigent criminal defendants.

The causal arrow, in this analysis, runs directly from governmental structure (federalism, which limits or weakens centralized bureaucratic accountability) to adversarial legalism, expressed in a lawyer-activated system that seeks accountability through private lawsuits. But federalism does not automatically give rise to legal rights to challenge local officials in court. To ensure that local officials follow national rules, federal lawmakers and officials have other options. The feds can insist on detailed reporting by local officials. They can send in federal auditors. They can suspend or cut off federal funding in the event of noncompliance. They can bypass local government by funding new federal administrative offices to implement federal laws.

It took lawyers' arguments about the special virtues of adversarial legalism to persuade the Supreme Court to extend most Bill of Rights provisions to the states; to read the Sixth Amendment's right to counsel to require affirmative governmental provision of free defense lawyers; to imply (that is, create) private rights of action to bring tort suits for damages against state and local officials under federal civil rights law; ${ }^{55}$ to imply a Fourth Amendment right to sue state and local law enforcement officials for illegal searches and seizures; 56 to empower advocacy groups to obtain injunctions against government agencies for not withholding funds from local agencies alleged to have violated federal civil rights laws. ${ }^{57}$

I am not suggesting that these decisions were undesirable but only that they do not flow ineluctably from the fact that federalism limits direct national governmental control over local officials. It is hard to imagine German or British courts dealing with such a structural problem by inventing textually unstated private rights to sue local officials. The American court decisions mentioned were encouraged and legitimated by a legal culture, created primarily by legal scholars and lawyers, that values adversarial legalism as a means of accountability and endorses judicial creativity to "do justice" when other branches of government seem to be failing. Put otherwise,

55. For a thorough account, see Schuck, Suing Government (cited in note 33).

56. Bivens v. Six Unknown Agents of Federal Bureau of Narcotics, 403 U.S. 388 (1971). In 1980-81, based on docket studies in three federal court districts, an estimated 5,500 "constitutional tort" cases were filed in the federal courts, accounting for about $12 \%$ of all federal tort actions. S. Schwab \& T. Eisenberg, "Explaining Constitutional Tort Litigation: The Influence of the Attorney Fees Statute and the Government as Defendant," 73 Comell L. Rev. 719 (1988).

57. Jeremy Rabkin, Judicial Compulsions: How Public Law Distorts Public Policy (New York: Basic Books, 1989). 
lawyers' legal culture ${ }^{58}$ operated as an "intervening variable" between the underlying political structure and the ultimate emphasis on adversarial and legalistic control mechanisms.

Consider also the landmark federal Education for All Handicapped Children Act (P.L. 94-142), enacted in 1973, requiring local public schools to provide all children, regardless of handicap, an "appropriate public education." How was compliance to be assured in thousands of school districts, controlled by locally elected boards? The solution chosen-in contrast to the method adopted in Great Britain ${ }^{59}$ - was to subject local decision making to detailed due process procedures. Parents of handicapped children were given legal rights to participate in a prescribed meeting with educational officials, to negotiate a contractual educational plan for their child, and to appeal, first administratively, then to court, from educational plans with which they disagreed. In consequence, educational decisions often have led to adversarial, legalistic hearings, ${ }^{60}$ and federal courts became the principal forums for defining "appropriate public education." 61

Congress's decision to rely on lawyer-assisted private legal challenge, rather than top-down bureaucratic review, to protect the interests of handicapped children seems to flow directly from the limitations imposed by American political structure, in this case a politically decentralized educational system. But that decision was not inevitable. Early versions of P.L. 94-142 called for oversight of school-level compliance by federal or state administrative entities. However, two public interest law firms-the Children's Defense Fund and the California Rural Legal Assistance Foundation-" played a key role . . . as advisors to the congressional conferees. . . .

58. By "legal culture" I refer to the discourse, ideas, and attitudes about law and litigation that pervade the world of law teachers, practicing lawyers, judges, legislators, administrative officials, law enforcement officials, and legal writers. I wish to distinguish this "elite" legal culture from the popular or "mass" legal culture that figures prominently in the work of Lawrence M. Friedman, as in his Total Justice (cited in note 39) and The Republic of Choice: Law, Authority and Culture (Cambridge, Mass.: Harvard University Press, 1990). Of course, popular legal culture influences elite legal culture and vice versa. Law students watch "L.A. Law" on television and lawyers serve as consultants to "L.A. Law" writers. But for systematic survey evidence that there are striking differences between lawyers' and mass attitudes concerning core legal values (due process, civil liberties), see $\mathrm{H}$. McClosky \& A. Brill, Dimensions of Tolerance: What Americans Believe about Civil Liberties (New York: Russell Sage Foundation, 1983).

59. Kirp, 34 World Politics (cited in note 6).

60. D. Neal \& D. Kirp, "The Allure of Legalization Reconsidered: The Case of Special Education," in D. Kirp \& D. Jensen, eds., School Days, Rule Days: The Legalization and Regulation of Education 355 (New York: Falmer Press, 1986) ("Neal \& Kirp, 'Allure of Legalization"): "Adversariness and legalism seem to characterize the conduct of hearings. Rather than adopting an informal negotiating format, the due process hearings tend to provide a forum for culmination of long-term bad relations between the school and the parents involved. Involving lawyers aggravates the situation, rendering proceedings more legalistic. Emphasis on compliance with procedural matters such as notices, signatures, and time deadlines offers an easy substitute for harder substantive questions."

61. R. Shep Melnick, Between the Lines: Interpreting Welfare Rights (Washington, D.C.: Brookings Institution, 1993). 
Their experience [in civil rights and poverty litigation] produced a belief in the efficacy of rights, courts and court-like procedures, and profound mistrust of bureaucratic accountability."62

Here, too, a legal culture dedicated to accountability via due process procedures and judicially enforceable rights seems to have operated as an intervening variable, intensifying the federal government's propensity to rely on locally exerted collateral legal pressures. And in the P.L. 94-142 case, the influence of lawyer lobbyists in shaping the implementation method was palpable.

Consequently, it seems appropriate to propose a third hypothesis, set forth in schematic form in figure 2: the norms and actions of American lawyers act as a significant secondary cause of adversarial legalism.

\section{FIGURE 2}

\section{Lawyers as Secondary Cause of Adversarial Legalism}

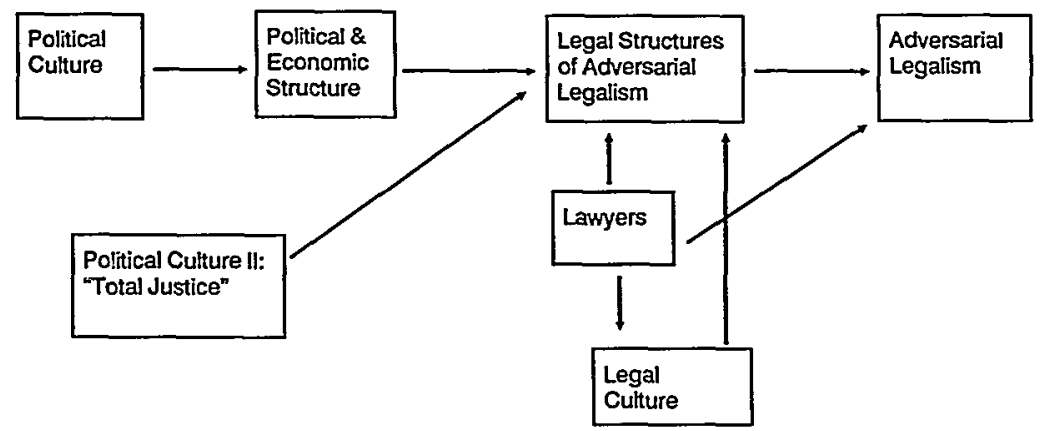

The next task is to discuss available evidence supporting of the "lawyers-as-secondary-cause" hypothesis. Lawyers' causal impact is channeled, I will attempt to demonstrate, through three streams of activity:

1. Promoting legal ideas and tules that legitimate adversarial legalism and extend the realm of issues, or governmental and economic functions, subject to that mode of governance.

2. Aggressive case by case advocacy, in which some lawyers choose to exploit or magnify (rather than temper) the characteristics of adversarial legalism.

3. Mounting organized resistance to reforms that would reduce adversarial legalism.

The sections that follow provide a preliminary sketch of each. But first, two methodological issues must be mentioned. 


\section{Lawyers or Clients}

When lawyers push for statutes and judicial rulings that extend adversarial legalism, and when they engage in aggressive case-by-case advocacy, they often do so on behalf of clients whose interests they are paid to advance. How, then, can we properly view the lawyers, rather than the clients and interest groups, as the "causes" of adversarial legalism? Often we cannot. But in a number of settings, situations, and roles, lawyers plausibly can be thought of as acting wholly or partly "on their own account."

First, independent responsibility for their actions can be imputed to members of the legal profession when they work in positions, situations, or settings in which they are not formally representing particular clients, organizations, or associations. In this category are judges, law professors, bar association officers and committee members, and members of law reform commissions. The category also includes lawyers serving as legislators, legislative staffers, and policymakers in administrative agencies or elsewhere in the executive branch of government. Lawyers in those positions may have felt obligations to particular clients and interests, but the roles they occupy formally obligate them to serve a wider public interest as they discern it. Thus when they promote legal measures that would expand rather than those that would retard adversarial legalism, they can be regarded as having made their own choices.

Second, some lawyers enjoy a great deal of discretion in deciding which clients or interests to represent and how to do so. For example, prosecutors at all levels of government, lawyers in public interest law firms, and lawyers who serve as leaders of advocacy groups are expected to work for "the public interest" as they see it. They typically have considerable authority to decide "on their own" whether and how to litigate and what kind of legal or policy arguments to make. ${ }^{63}$

Third, lawyers who are financially dependent on a particular kind of litigation have their own economic stake, independent of the interests of particular clients, in initiating certain kinds of litigation and in fighting for legal rules and institutions that foster adversarial legalism in their area of practice. The most obvious examples are plaintiffs' attorneys who work on contingency fees, but the category actually is broader. ${ }^{64}$

63. For example, staff attorneys in national environmental groups told a researcher that decisions to litigate are for the most part made in a decentralized way by the lawyers, usually "by the individual advocates who are working on the particular matter." Cary Coglianese, "Environmental Litigation as a Political Strategy" (presented at Law \& Society Association annual meeting, 1993).

64. During the 1930s, many small firm labor lawyers opposed New Deal legislation that would divert disputes over unfair labor practices from courts to more informal, lawyerless administrative forums. Shamir, 27 Law $\mathcal{E}^{8}$ Soc'y. Rev. (cited in note 22). 
Fourth, some lawyers have reputational interests, philosophies, or personalities that may lead them to seek to engage in adversarial legalism, and they may influence clients to accept the lawyer's preferred course of action.

Sections IV, V, and VI of this article present numerous examples of lawyers acting as "causes" of adversarial legalism; they tend to fit into one of these four categories of relatively independent lawyer choice.

\section{Lawyers as "Dampeners" of Adversarial Legalism}

In a society pervaded by the threat of legal action, lawyers for business corporations, school boards, and other organizations undoubtedly prevent litigation simply by spreading the word about potential liabilities. ${ }^{65}$ In their everyday practice, corporate lawyers attempt in many ways to forfend litigation, drafting imaginative contractual provisions for resolving conflict in case business earnings decline or debts go unpaid. ${ }^{66}$ Many attorneys decline to advance claims or defenses that seem to them unjustified in law or in equity. ${ }^{67}$ Other lawyers, emphasizing the costliness of the adversarial process, push clients intent on moral vindication to accept financial compromise. ${ }^{63}$

Some American lawyers go further, systematically trying to reduce the overall volume of adversarial legalism. Bar associations dominated by elite lawyers often have fought against "ambulance chasing" or increased litigation in hopes of enhancing the image of the profession. ${ }^{69}$ In some corporations, the general counsel has insisted on using private mediation firms, rather than litigation, to resolve entire categories of disputes; the leading mediation firms are run and staffed by lawyers and former judges. ${ }^{70}$ Some law professors have been at the forefront in recommending no-fault insur-

65. See Kagan \& Rosen, 37 Stan. L. Rev. 399 (cited in note 51) (corporate lawyers as "conduits"), and William K. Muir, Jr., Law and Attitude Change 112 (Chicago: University of Chicago Press, 1967) ("Muir, Law and Attitude Change") (school board lawyer who successfully promoted compliance with Supreme Court decision barring prayer in public schools).

66. Ronald Gilson, "Value Creation by Business Lawyers: Legal Skills and Asset Pricing," 94 Yale L.J. 239 (1984); Kagan \& Rosen, 37 Stan. L. Rev. (cited in note 51).

67. Reporting on his interviews of Wisconsin attorneys in connection with their handling of consumer claims, Macaulay, 14 Law \& Soc'y Rev. (cited in note 16), says:

A number of attorneys suggested that a lawyer has an obligation to judge the true merits of a client's case and to use only reasonable means to solve problems. . . For example, several attorneys were very critical of other members of the bar who had used the Wisconsin Consumer Protection Act so that a lender who had violated what they saw as a "technical" requirement of the statute would not be paid for a car which the consumer would keep. While this might be the letrer of the law, apparently a responsible lawyer would negotiate a settlement whereby the consumer would pay for the car but would pay less as a result of the lender's error.

68. Id. at 153-55; Austin Sarat \& William L. F. Felstiner, "Law and Strategy in the Divorce Lawyer's Office," 20 Law \& Soc'y Rev. 93 (1986).

69. Shamir, 27 Law \& Soc'y Rev. at 374 (cited in note 22).

70. Ellen Joan Pollock, "Mediation Firms Alter the Legal Landscape," Wall St. J., 22 March 1993, at B1, B6. 
ance schemes to replace costly tort litigation..$^{71}$ During the administrations of Presidents Reagan and Bush, government lawyers persuaded conservative judges to restrict appeals to federal courts from state criminal convictions.

Consequently, one might argue that even if some members of the American legal profession consciously and on their own account work to amplify adversarial legalism, there are even more members of the profession who work to dampen it. Perhaps, then, the net contribution of lawyers is to reduce adversarial legalism.

Perhaps, but probably not. The dampeners undoubtedly reduce adversarial legalism below the level that would exist if they had instead become amplifiers. But the relative number of lawyers in each camp does not resolve the question. The burglary rate can go up even if most people try to deter burglary. Relatively small numbers of determined people can have a big impact. The fact remains that adversarial legalism, by most measures, has increased in the last quarter-century. The issue is whether the actions of lawyers-not all lawyers, but lawyers-have played a role in that net increase, even though many of their professional brothers and sisters may have prevented the increase from being greater.

The tension between amplifiers and dampeners, however, raises another issue. If adversarial legalism has increased, and if the legal profession has played a causal role in that regard, that suggests that the profession itself has changed, and in such a way as to enhance the relative power and impact of amplifiers as compared to dampeners. Thus the question to be examined, ideally, is not only how lawyers help generate adversarial legalism, but whether there has been any discernible change in American lawyers' ideas, practices, and professional roles.

The point has come, then, to consider what evidence might be adduced to support the lawyers-as-net-amplifiers thesis. The evidence, it must be admitted, is scattered and often anecdotal. The inferences drawn, if persuasive, rest more on their plausibility than their conclusiveness. Evidence of change over time, while offered whenever possible, sometimes rests only on general impressions that numerous legal practices mentioned-such as public interest lawyering, corporate takeover and class action litigation, toxic tort cases, SLAPP suits, Superfund litigation, and computerized clearing houses for plaintiffs' product liability lawyers-simply did not exist 30 years ago or were far less common. Nevertheless, it seems worthwhile to map even selected portions of the territory with whatever crude tools are at hand.

71. R. Keeton \& J. O’Connell, Basic Protection for the Traffic Victim: A Blueprint for Reforming Automobile Insurance (Boston: Little, Brown, 1965); Stephen D. Sugarman, Doing away with Personal Injury Law: New Compensation Mechanisms for Victims, Consumers, and Business (New York: Quorum Books, 1989). 


\section{LAWYERS AND THE CULTURE OF ADVERSARIAL LEGALISM}

Independent causal importance can be imputed to lawyers, first of all, as principal actors in propagating a legal culture that legitimates adversarial legalism, legal malleability, and judicially enforceable private rights as a desirable mode of government. Second, lawyers often act on their own account in advocating new legal rules that expand adversarial legalism. Abundant evidence exists of both activities in three arenas discussed below: legal education and scholarship; lobbying in judicial and legislative institutions; and formulating legal ethics that encourage adversarial legalism.

\section{A. American Legal Culture and American Law Schools}

\section{Law as Politics by Other Means}

In March 1993, an Alabama trial court judge wrote a 125-page opinion declaring that the state's entire public school system violated the state constitution's mandate to "maintain a liberal system of education throughout the state." The system was unconstitutional not because of discrimination but because, Judge Eugene Reese said, it doesn't give Alabama students an adequate education. The academic performance of many students, the judge found, fell short of basic standards, and many school buildings were woefully ill-supplied and badly maintained. Judge Reese's opinion specified that the schools, inter alia, must provide students with an opportunity to attain sufficient skills to compete with other students throughout the world and "sufficient understanding of the arts to enable each student to appreciate his or her cultural heritage and the cultural heritages of others."72

This decision, while remarkable both for its creativity in interpreting the constitutional text and for its ambition, nevertheless exemplifies a vision of the law and the courts' role that is common, if not predominant, in American legal culture. The law as laid down, in this view, is not a set of authoritative norms. Law is a set of tools, evolving guides to the realization of broader ends, primary among which are individual and social justice. That instrumentalist, social engineering view of law and of the proper role of judges contrasts sharply with the legal culture of the civil law countries of Western Europe and even of Great Britain, America's common law ancestor. In other democracies, law is generally regarded as a set of relatively stable, binding rules or principles. Changing law to attain social ideals is

72. Alabama Coalition for Equity v. Hunt (1993), Circuit Court for Montgomery, Ala., Civil Action No. CV-90-883-R. (excerpted in Edward Felsenthal, "School System in Alabama Gets 'F' from Court," Wall St. J., 6 April 1993, at B1). See also Peter Applebome, "Its Schools Ruled Inadequate, Alabama Looks for Answers," N.Y. Times, 9 June 1993, at A1, A13. 
much more likely to be viewed as a job for democratically elected parliamentary governments. ${ }^{73}$

The instrumental view of law and of the judicial role, of course, is by no means uncontested in the United States. Its predominance ebbs and flows with political eras, issues, and movements. It varies across courts in the same era. But it has long been a major stream in American legal culture. And most important, it has flowed with unusual energy and turbulence in recent decades. High courts seek control over their dockets, they candidly acknowledge, so as to maximize the courts' capacity to deal with major policy issues. ${ }^{74}$ Chief Justice Earl Warren of the U.S. Supreme Court and Judge Roger Traynor of the California Supreme Court, creative, precedent-discarding instrumentalists, are treated as exemplars of the American judicial tradition. ${ }^{75}$ To the extent that the American legal profession-the social grouping in which legal culture is most consciously and continuously articulated, debated, shaped, and reshaped-endorses and promotes an instrumentalist vision of law and legal change, then it seems fair to infer that lawyers themselves, as advocates and as judges, help extend adversarial legalism.

\section{Law Professors and the Culture of Adversarial Legalism}

After the above-mentioned Alabama trial judge declared the state school system unconstitutionally inadequate, Professor Eric Neisser of Rutgers University Law School told a news reporter, "I think [courts] would like to get out of the business [of defining standards schools must uphold], but unless someone takes control of the problem, the courts feel that they have to respond to the constitutional mandate."76 Neisser, moreover, apparently endorsed that view, that is, if the other branches of government are not doing the job adequately, the courts, however reluctantly, are obliged to see that basic justice is done.

Is that what American law professors teach future advocates, judges, legislative staffers, and politicians? Many American law professors, surely, do not. They might teach that whether the other branches of government are failing to "do the job" or "take control of the problem" depends on a complex set of educational, economic, and political judgments that the courts are not well suited to evaluate. Some professors would argue that the courts are not likely to be able to solve the problem if they take it on, or

73. Atiyah \& Summers, Form and Substance (cited in note 11); R. Kagan, "What Makes Uncle Sammy Sue?" 21 Law \& Soc'y Rev. 717, 728-30 (1988).

74. R. Kagan, L. Friedman, B. Cartwright, and S. Wheeler, "The Evolution of State Supreme Courts," 76 Mich. L. Rev. 961, 980-84 (1978).

75. G. Edward White, The American Judicial Tradition (New York: Oxford University Press, 1976).

76. Felsenthal, Wall St. J., 6 April 1993, at B1. 
that the courts have no warrant to try without clear legal justification in the text of existing constitutions, laws and precedents.

Nevertheless, Neisser is not alone. ${ }^{77}$ I know of no survey that attempts to measure support for his instrumentalist philosophy among the law school professoriat. ${ }^{78}$ But when I ask law professors what they think their colleagues think, most say that a view much like Niesser's, if not predominant, is quite prominent. And few who attended an American law school a generation or two ago would deny that instrumentalism was less prominent then.

Comparative observers often note that when contrasted with legal education in England and Western Europe, current day American law schools promote a remarkably activist, instrumentalist image of law and the role of lawyers and judges. Atiyah and Summers observe that while English legal academics defer to barristers and judges in shaping law and legal culture, American law professors actively seek to shape legal culture, and through it, society, and have had a significant degree of success: "American law schools have been the source of the dominant general theory of law in America ... 'instrumentalism'. . . [which] conceives of law essentially as a pragmatic instrument of social improvement."79 Instrumentalism is embraced by many politically conservative as well as liberal professors, most prominently by adherents of the influential "law and economics" movement, who seek law reforms designed to enhance economic efficiency.

Whereas British law students are expected to learn the rules of rules as laid down in rather dogmatic textbooks, and Continental students are expected to learn and accept the theoretical underpinnings of their legal systems, American law students are taught to challenge or at least to question their country's law. They spend more time studying the most disputed cases than basic black letter doctrine. They are urged to analyze the merits of

77. See Owen Fiss, "Against Settlement," 93 Yale L.J. 1073, 1086-87 (1984), "Someone has to confront the betrayal of our deepest ideals and be prepared to turn the world upside down to bring those ideals to fruition." And that someone, Fiss argues, should be the courageous judge.

78. There are some surveys that address different but somewhat related issues. Charles Kelso, The AALS Study of Part-Time Legal Education (Washington, D.C.: Association of American Law Schools, 1972), found that teachers at larger "high resource schools" (primarily university law schools) thought that law schools should teach a more theoretical (and presumably more critical) approach to law, while those at "low resource" (usually proprietary) schools tended to think they should teach in a more positivist, law-applying manner. A Carnegie Commission on Higher Education survey (in 1969 and 1974) found that at least two-thirds of professors in the 20 top-ranked law schools agreed with the proposition that their institutions "should be actively involved in solving social problems." More than half of American law professors, and higher proportions in the top 20 law schools, identified themselves as politically "left or liberal," and only small percentages as "moderately or strongly conservative," which put them far to the left of most other academic and professional faculties. Carl Auerbach, "The Silent Opposition of Professors and Graduate Students to Preferential Affirmative Action Programs: 1969 and 1975," 72 Minn. L. Rev. 1233 (1988).

79. Emphasis added. J. Willard Hurst, Law and the Conditions of Freedom in the Nineteenth Century United States (Madison: University of Wisconsin Press, 1956); Horwitz, Transformation of American Law (cited in note 30). 
legal doctrines and judicial opinions in terms of the fairness, economic efficiency, or equality of their social consequences. ${ }^{80}$ They are prodded to formulate legal arguments that would support their gut feelings about what the results should be. The law reviews they edit bulge with articles calling for new legal rights and changes in old ones, along with essays stressing the indeterminacy of legal rules. ${ }^{81}$

American law students are taught by their professors that judges often are incompetent or as apt to be influenced by their political attitudes and allegiances as by the letter of the law..$^{82}$ The legal system, many American law professors implicitly suggest, is a field of political struggle, shaped by the play of creative lawyering and argumentation (at best) and by raw economic and political power (at worst). So the lawyer's job is to pick her way through that uncertain mine field, striving for justice as best she can when she sees an opening, whether as lawyer or judge. Not surprisingly, that is the view of the system that American lawyers convey to their clients. ${ }^{83}$

\section{Law Schools and Distrust of Governmental Power}

If judicial authority, viewed through the lens of American legal education, is not entirely reliable and rational, law schools suggest that the rest of government is even more likely to be arbitrary. In law school, American political culture's vague distrust of governmental competence is honed to a fine edge. "The best insurance against autocracy," says an introduction to the law, "is to diffuse power as much as possible throughout society. This is exactly what lawyers in America do!"84 If this country's biggest worry is

80. Atiyah \& Summers, Form and Substance 391 (cited in note 11): "[T] he primary aim is to teach the student a methodology-how to construct, analyze, compare, evaluate, and criticise arguments and decisions (including rules) and to 'project' lines of judicial decisions and legislation. In this way the instructor implicitly inculcates faith in the power of substantive reasoning, in policy arguments, rather than in the mere arbitrium of formal rules."

81. Michael Saks systematically compared American law reviews published in 1960 with those published in 1980 . He found that in 1960 "the ratio of articles criticizing [the legal status quo] to articles defending was 0.84 -for every article defending there was less than one article criticizing. For 1985 articles, the ratio had risen to 2.59 -more than two and a half articles criticizing doctrine for every article defending it." Saks, "Law Journals: Their Shapes and Contents, 1960 and 1985" at 5-6 (presented at Association of American Law Schools annual meeting, 1989).

82. The indeterminacy of rules and precedents was stressed by American Legal Realist scholars in the late 1920s and 1930s. It took another generation or two, however, before their views came to dominate legal education, forming the basic ground on which scholars of different philosophical camps sought new theories on which to base law. Today, reviewing the last decade's debates among the leading schools of legal thought, one professor concluded, "Now all sides agree that "in some ultimate sense law . . . is unavoidably political.'" Michael Wells, "Behind the Parity Debate: The Decline of the Legal Process Tradition in the Law of the Federal Courts," 71 Boston U. L. Rev. 609 (1991) (quoting Richard Posner, "The Decline of Law as an Autonomous Discipline: 1962-1987," 100 Harv. L. Rev. 761 (1987)).

83. Sarat \& Felstiner, 20 Law \& Soc'y Rev. 93 (cited in note 68).

84. Richard Moll, The Lure of the Law 10 (New York: Viking Press, 1990). 
defined as the threat of "autocracy"-rather than government too fragmented and mistrusted to achieve collective goals-it is no wonder that lawyers-to-be are taught, first and foremost, to question the bureaucrat's or the police officer's word, to favor strict (or at least "heightened") judicial scrutiny of legislative enactments for signs of bias or "rent-seeking," and to view due process procedures and lawyer-assisted access to the courts as the best way to structure governmental processes.

When American lawyers or policymakers call for the extension of legal rights, enforceable through litigation, they draw on a well-developed and familiar rationale. In the words of David Kirp (who is not an unalloyed enthusiast of that mode of governance):

Legalization is a vehicle by which individual citizens may redress the balance between themselves and the state or other powerful opposing interests. It provides access to individuals unable to summon the political resources needed to obtain a legislative majority in modern politics. It offers principled decision-making in an impartial, procedurallybalanced forum. It emphasizes accountability, administrative regularity and the reduction of arbitrariness. ${ }^{85}$

But for those who are skeptical about adversarial legalism's virtues, American legal culture offers no countervailing set of ideals. Opponents often argue that further legalization would be costly, or would overburden the courts, or would unduly curtail official discretion, or (perhaps most effectively) would be "a full-employment program for lawyers." But those are crimped, negative arguments, devoid of the high-sounding values that permeate the arguments for rights and for adversarial legalism. A countervailing ideal would favor collective goals over individual rights, legal stability rather than legal responsiveness, the notion that professional governmental officials are better guarantors of the public interest and equity than are judges and juries. Those are ideals discussed in European legal scholarship. ${ }^{86}$ But that is not what one generally encounters in American legal scholarship and classroom talk. ${ }^{87}$ In the legal culture developed in American law schools, therefore, the proponents of adversarial legalism tend to occupy the moral high ground.

\section{Law Professors as Lobbyists}

The generally pro-adversarial legalism views of the American law professoriat are channeled directly to the judiciary. Some legal scholars

85. Neal \& Kirp, "Allure of Legalization" at 357 (cited in note 60).

86. Damaska, Faces of Justice (cited in note 9).

87. Mary Ann Glendon, Rights Talk: The Impoverishment of Political Discourse (New York: Free Press, 1991). 
often are called on to write briefs in controversial Supreme Court cases. Writing about N.Y.U. law professor Anthony Amsterdam, a leading expert in capital punishment issues, a legal reporter asserts, "his consultant services are virtually mandatory in death penalty challenges." 88 Student law review editors move directly to the chambers of high court judges, bringing the latest scholarship to the pages of judicial opinions. Influential law professors rush their articles into print in time to be quoted in briefs in controversial cases. Atiyah and Summers write:

A striking and far from isolated illustration of the extraordinary impact which academic ideas have on the daily administration of law can be found in the way in which in the 1970s and 1980s American state courts across the country accepted the arguments of a junior law professor ... for allowing punitive damages more generously in products liability cases. ${ }^{89}$.. . Indeed, almost the whole of the modern law of strict products liability in tort has originated in academic writings. ${ }^{90}$

Law professors also serve as reporters and chief drafters of the American Law Institute's influential "model statutes" and "Restatements" of the common law-documents that often have advocated more expansive legal rights and more equal (hence easier) access to courts. ${ }^{91}$

The most important influence of the law schools, however, has been indirect. They shape a legal culture that is invoked, day in and day out, by practicing lawyers and legally trained governmental officials (including judges) when they make arguments based on an instrumentalist vision of law; that validate judicial policymaking under a broad range of circumstances; and that call for judicially enforceable legal rights as a way of implementing public policy. ${ }^{92}$

88. Emily Couric, "Profiles in Power," Nat'l L.J., 15 April 1985, Spec. Rep., at 19.

89. Citing David Owen, "Punitive Damages in Products Liability Litigation," 74 Mich. L. Rev. 1257 (1956), "an article said to have been cited within a few years in at least 20 jurisdictions." Atiyah \& Summers, Form and Substance 401-2 (cited in note 11).

90. Id. See George Priest, "The Invention of Enterprise Liability: A Critical History of the Intellectual Foundations of Modern Tort Law," 14 J. Legal Stud. 461 (1985). But see Gary Schwartz, "The Beginning and the Possible End of the Rise of Modern American Tort Law," 26 Ga. L. Rev. 601 (1992).

91. ALI Committees, of course, do not always endorse rule changes that encourage adversarial legalism. For a fascinating case study, see Edward Rubin, "Thinking Like a Lawyer, Acting Like a Lobbyist: Some Notes on the Process of Revising UCC Articles 3 and 4," 26 Loy. L.A. L. Rev. 743 (1993). Rubin's account does indicate, however, that both ALI as an institution and individual law professors not infrequently lobby legislatures for the changes they prefer.

92. It is not only in the United States, of course, that legal scholars are influential. See, e.g., Martin Weston, An English Reader's Guide to the French Legal System 117 (New York: Berg, 1991); John Henry Merryman, The Civil Law Tradition 56 (2d ed. Palo Alto, Cal.: Stanford University Press, 1985). What matters for our purposes is whether the approach to law recommended by the scholars fosters adversarial legalism, and that, far more than their French or German counterparts, is what the American professoriat tends to do. 


\section{B. Extending Adversarial Legalism in Courts and Legislatures}

Connecticut attorney Robert Farr, when serving as a state legislator, tried unsuccessfully to push through legislation banning smoking in restaurants. When Congress passed the 1990 Americans with Disabilities Act, designed primarily to bar workplace discrimination against disabled people, Farr saw another opportunity. The American Lung Association put him in touch with three mothers of children with asthma. On their behalf, Farr brought suit against Wendy's, McDonalds, and Burger King, arguing that by failing to bar smoking entirely-their current practice was to restrict smoking to some sections-the restaurants discriminated against people with respiratory ailments, forcing them to eat elsewhere. ${ }^{93}$

Farr may or may not win his case. While his cause is arguably just, it is highly unlikely that Congress, in enacting the Disabilities Act, intended to bar smoking in all stores, restaurants, and workplaces. On the other hand, the act's language is both sweeping and unclear, so Farr had at least a chance of winning. Many ADA suits have been filed on behalf of injured workers in order to obtain larger damages than those provided by workers' compensation laws-although again, that probably was not Congress's intent. ${ }^{94}$ Like Farr, many American lawyers feel no compunction about using litigation to persuade the courts to extend statutory rights in previously uncontemplated ways; ${ }^{95}$ their legal culture, which values legal creativity in the pursuit of justice, validates their behavior. In day-to-day advocacy, therefore, lawyers (not all, but some, and cumulatively many) pound away at the frontiers of law. They lose many cases, of course. But in the aggregate they extend the universe of litigable claims a bit further and thereby reinforce the culture of adversarial legalism.

\section{Creative Judging}

Innovative lawyering aimed at extending the boundaries of adversarial legalism would be fruitless, of course, if judges were not responsive. Consider again, therefore, the Alabama trial judge who declared the state school system inadequate and hence unconstitutional. If his decision is upheld, the threat of appeal to court will become a pervasive feature of decision making concerning funding and policy in Alabama public schools. The judge's decision was "invited," one might say, by the basic structural factors discussed earlier-growing expectations of "total justice" (in this case the social injustice of substandard educational facilities and programs) and a fragmented political system seemingly incapable of establishing and administering na-

93. Edward Felsenthal, "Disabilities Act Is Being Invoked in Diverse Cases," Wall St. J., 31 March 1993, at B1.

94. Id.

95. Atiyah \& Summers, Form and Substance 381-82. 
tionwide educational standards. Still, the Alabama judge's decision was not "compelled" by law or by political pressure. It was the decision of a lawtrained judge, secured in his position by the traditions of judicial independence, responding simultaneously to a serious social problem and to legal and policy arguments advanced by public interest lawyers. To the extent this phenomenon is common - that is, judges, acting without great political pressure, in response to perceived injustice and innovative legal arguments, make litigation-encouraging policy decisions-then it seems fair to regard the legal profession as a significant "cause" of adversarial legalism. It is common. Hence lawyers do cause adversarial legalism.

Of course, many, perhaps most, American judges are judicially or politically conservative, inclined to reject arguments that would expand adversarial legalism. But that means only that the incidence and intensity of adversarial legalism is lower than it would be if most judges were "activists." New legal rights and remedies established by the innovative judges tend to persist and spawn litigation despite the reluctance of others to expand rights and remedies further. And in the past 30 years "net" judicial contributions to adversarial legalism have been great. American judges, acting without political or legal compulsion, have transformed the law in a wide range of policy areas, particularly constitutional law and torts, as suggested by this selective but still lengthy list:

- Judicial abolition of the defense of contributory negligence in tort, in favor of a claim-encouraging comparative negligence standard

- Judicial abandonment of the litigation-restricting "locality" rule for determining the standard of care in medical malpractice cases, giving rise to a lively field of litigation

- Judicial creation of liability for "toxic torts"96

- Judicial creation of causes of action for dismissal of employees without "just cause"

- Judicial creation of implied warranties of habitability for rental housing, which has introduced a larger measure of adversarial legalism into eviction procedures

- Judicial extension to all criminal courts of the "exclusionary rule" for illegally obtained evidence-giving rise to a new field of pretrial motion process and appellate litigation

- Judicial creation of a constitutional right to free legal counsel for indigent criminal defendants (initially in felony cases and appeals, later in most misdemeanor cases), and then to "adequate representation" (raising many new grounds for appeal)

96. Peter Huber, "Environmental Hazards and Liability Law," in R. Litan \& C. Winston, eds., Liability: Perspectives and Policy (Washington, D.C.: Brookings Institution, 1988).

97. James Dertouzos et al., The Legal and Economic Consequences of Wrongful Termination (Santa Monica, Cal.: RAND Institute for Civil Justice, 1992). 
- Judicial creation of a constitutional right of privacy, which made litigation a pervasive part of policymaking concerning abortion policy

- Judicial creation of constitutional rights to decent treatment in prisons and mental institutions, which brought litigation, lawyering, and judicial supervision into the policymaking and funding process in scores of state prison systems, jails, and treatment facilities

- Judicial creation of new due process rights for welfare recipients, persons subject to involuntary commitment to mental hospitals, and school children threatened with disciplinary suspensions-giving rise to new, institutionalized forms of adversarial legalism

The judges who issued these decisions often were responding to deep social concerns, widely expressed in the media or by prominent politicians. Indeed, many of these decisions have been acquiesced in and even extended by legislatures. Lawyers and judges, therefore, did not act alone, without encouragement from the wider society.

Nevertheless, the decisions mentioned and the strategy of policy change they reflected were triggered and shaped primarily by lawyers. They were justified and defended by lawyer-dominated legal discourse ${ }^{98}$ that endorsed social problem solving via judicial action and advocated litigation as a mechanism for realizing the values articulated in the reform-oriented judicial decisions. For example, the judicial rulings extending liability law were explicitly justified in social engineering terms. The advocates' briefs and judges' opinions argued that enhanced liability would force businesses, hospitals, and municipalities to internalize harmful externalities, reducing aggregate social costs. The constitutional decisions mentioned above reflected the view implicit in Neisser's comments on the Alabama school case: if other political bodies are not dealing adequately with the social problem dramatized by the case at hand, then judges, however reluctantly, are duty bound to forge a responsive legal right and a judicially enforceable remedy. And each creative judicial decision, covered widely in the press and given prominence in law school casebooks, served to validate and deepen the legal culture's endorsement of adversarial legalism as an essential mechanism of government.

Policy-oriented judges also extend statutes in ways not contemplated by the original legislators. Earlier, reference was made to judicially implied private rights to sue governmental officials for insufficiently aggressive enforcement of civil rights and regulatory statutes. Civil rights lawyers and sympathetic judges reshaped the 1965 Voting Rights Act, which guaranteed equal rights to vote, into a vehicle for judicial invalidation of electoral rules

98. For an insightful account of how lawyers help build acceptance for controversial decisions, see Muir, Law and Attitude Change (cited in note 65) (school board lawyer and the Supreme Court's school prayer decision). 
under which minority candidates have difficulty winning elections; 99 in consequence, few electoral redistricting statutes now take effect without a lawsuit. Similarly, judges read the National Environmental Protection Act to give environmental groups the right to sue agencies for inadequate environmental impact statements. ${ }^{100}$ Not surprisingly, a cross-national comparison of styles of statutory interpretation classified the American judiciary as the most free-wheeling. ${ }^{101}$

\section{Organized Lawyering for Legal Change}

Many of the innovative judicial rulings mentioned above, and others as well, culminated systematic campaigns of legal advocacy. In no other nation's legal system are there such a large number of, or such effective, politically motivated legal advocacy organizations-acting primarily on their own policy agendas, relatively free from pressure from particular clients. The prototypes were the American Civil Liberties Union and the NAACP Legal Defense Fund. Through systematic litigation, often aided by law review articles written by allied legal scholars, dedicated ACLU and NAACP lawyers were instrumental in persuading courts to expand the legal rights of criminal suspects, persons charged with capital crimes, opponents of school prayer, victims of racial discrimination, and proponents of busing to achieve racial balance in schools-and to institutionalize adversarial legalism as a means for protecting those rights. The NAACP, the ACLU, and the National Lawyers Guild successfully lobbied Congress for a 1964 Civil Rights Act provision authorizing awards of attorneys' fees for successful private litigants. ${ }^{102}$

In the late 1970s, the Ford Foundation funded a diverse group of public interest law firms, specializing in litigation on behalf of ostensibly underrepresented interests. ${ }^{103}$ Congress authorized attorney fee recovery in many

99. Abigail Thernstrom, Whose Votes Count? Affirmative Action and Minority Voting Rights (Cambridge, Mass.: Harvard University Press, 1987).

100. Serge Taylor, Making Bureaucracies Think: The Environmental Impact Statement Strategy of Administrative Reform (Palo Alto, Cal.: Stanford University Press, 1984). Judicial interpretations of NEPA helped reinforce the role of environmental specialists in the Forest Service and the Corps of Engineers, but also made adversarial legalism a recurrent feature of governmental efforts to build highways and license power plants, implement forestry plans, dredge harbors, construct waste disposal facilities, and issue offshore oil exploration leases.

101. R. Summers \& M. Taruffo, "Interpretation and Comparative Analysis," in D. N. MacCormick \& R. Summers, eds., Interpreting Statutes: A Comparative Study (Aldershot: Dartmouth Publishing, 1991).

102. K. O'Connor \& L. Epstein, "Bridging the Gap between Congress and the Supreme Court: Interest Groups and the Erosion of the American Rule Governing Awards of Attorneys' Fees," 28 W. Pol. Q. 238, 239-40 (1985).

103. Robert L. Rabin, "Lawyers for Social Change: Perspectives on Public Interest Law," 28 Stan. L. Rev. 207 (1976). 
major pieces of legislation, and litigation became a mainstay funding source for "private attorneys general."104

In the past 20 years, lawyer-dominated advocacy organizations have filed innumerable lawsuits, appeals, and amicus briefs to extend welfare rights, tenants rights, children's rights, women's rights, consumers' rights, disabled and mentally handicapped persons' rights, and the rights of criminal suspects and prisoners. Many have been successful. ${ }^{105}$ More recently, politically conservative public interest law firms have been established, and have had some limited success in persuading courts to expand the constitutional rights of property owners vis-à-vis regulatory restrictions and exactions-thereby establishing a new field of litigation.

Loose networks of plaintiffs lawyers regularly are formed on an ad hoc basis to lobby the courts for expanded legal rights for victims of particular hazards, such as asbestos, tobacco products, or pharmaceutical products. The lawyers circulate newsletters, operate clearing houses, and hold conferences to discuss possible legal arguments. ${ }^{106}$ Trial Lawyers for Public Justice, a public interest law firm modeled on the ACLU, pursues novel damage claims and appellate legal rulings that will broaden (or preserve) the reach of liability law. ${ }^{107}$

It is not only "private attorneys general" who lobby the courts for new legal rights and procedural guarantees. Ambitious public prosecutors-not a majority of them, but enough to make a difference--seek to enhance their reputations by "making law." In the 1960s and 1970s, according to Suzanne Weaver's study of the Antitrust Division of the Justice Department, lawyers competed to devise innovative legal theories that would support path-breaking prosecutions; winning spectacular victories and extending the reach of

104. O'Connor \& Epstein, 38 W. Pol. Q. at 241-45; Michael Greve, "Environmentalism and Bounty Hunting," 97 Pub. Interest 15 (1989). According to the Council on Competitiveness established by the Bush administration, by 1990 Congress had enacted more than 150 one-way fee-shifting statutes, under which plaintiffs who prevail can recover lawyers' fees from losing defendants, while victorious defendants get no such recovery.

105. For selected accounts of activist public interest lawyering that extended adversarial legalism into new areas of welfare, educational, regulatory, mental health, and penal policy, see W. Robert Curtis, "The Deinstitutionalization Story," Pub. Interest, Fall 1986, at 34; Robert Mnookin, ed., In the Interests of Children: Advocacy, Law Reform and Public Policy (New York: W. H. Freeman, 1985); Jeremy Rabkin, Judicial Compulsions: How Public Law Distorts Public Policy (New York: Basic Books, 1989); John J. Dilulio, Jr., ed., Courts, Corrections and the Constitution (New York: Oxford University Press, 1990).

106. See Robert Rabin, "Institutional and Historical Perspectives on Tobacco Tort Liability," in R. Rabin \& S. Sugarman, eds., Smoking Policy: Law, Politics, and Culture 110, 128 n.27 (New York: Oxford University Press, 1993) (discussing Tobacco Products Liability Project); David Stipp, "Dogma in Doubt: Extent of Lead's Risk to Kids, Need to Remove Paint," Wall St. J., 16 Sept. 1993, at A1, A12 (on newsletter concerning lead litigation); Bill Richards, "Elusive Threat: Electric Utilities Brace for Cancer Lawsuits Though Risk Is Unclear," Wall St. J., 5 Feb. 1992, at A1 (computerized data bank by coalition of law firms named "Electromagnetic Radiation Case Evaluation Team").

107. Andrew Blum, "Plaintiffs' Activists Celebrate," Nat'l L.J., 19 Oct. 1992, at 1. 
antitrust law seemed to be their overriding concern. ${ }^{108}$ Similarly, in the wake of Watergate, U.S. Attorneys crafted legal arguments that transformed the federal Mail Fraud Act, the Hobbs Act, the Travel Act, and the RICO (Racketeer Influenced and Corrupt Organizations) statute, none of whose "statutory language nor . . . legislative histories . . . authorize their application to local political corruption," into vehicles for prosecuting state and local officials. ${ }^{109}$

Persistent advocacy by claimants' lawyers gradually transformed California's workers compensation program, originally designed to provide insured benefits to injured workers without costly legal conflict, into an intensely adversarial and legalistic system. ${ }^{110} \mathrm{~J}$. Anthony Kline, legal affairs secretary to Governor Brown between 1975 and 1980, says, "The lawyers began to take over, The more lawyer involvement you get, the more procedural rules you get. The labor union movement gradually became dependent on the lawyers."111 In 1990, more than a third of workers compensation claims resulted in litigation; litigation costs amounted to two-thirds the average award in disputed cases. ${ }^{112}$ In the 1980 s, claimants' attorneys persuaded the courts to extend coverage to disabilities, physical or emotional, caused by workplace-generated stress. Stress claims are both costly and difficult to disprove; along with back injury claims, they generate a disproportionate amount of litigation. ${ }^{113}$ This intense, lawyer-driven legal advocacy is precisely what distinguishes workers compensation and other American administrative. programs from similar ones in Great Britain, for example, where dispute resolution in administrative "courts" and forums remains informal and inexpensive. ${ }^{114}$

108. Suzanne Weaver, "Anti-trust Division of the Department of Justice," in James $Q$. Wilson, ed., The Politics of Regulation (New York: Basic Books, 1980).

109. Arthur Maass, "Public Policy by Prosecution," Pub. Interest, Fall 1987, at 107, 114.

110. Philippe Nonet, Administrative Justice (New York: Russell Sage Foundation, 1969).

111. Dan Walters, "Workers Compensation: A New Approach to an Old System," Cal. Law., Feb. 1983, at 40, 41.

112. In 1990, California's statutory benefit levels for workers compensation-which tends to reflect the lobbying strength of organized labor-were comparatively low, ranking 34th among the 50 states. But in terms of average cost per worker (47 cents for every dollar of payroll), California ranked about third. "Twitching Millionaires," Economist, 3 Oct. 1992, at 29. A major reason was a high litigation rate, reaching nearly $36 \%$ of claims. California Workers Compensation Institute (CWCI), "Research Notes" (San Francisco: CWCI, 1991). Direct litigation costs-fees for both sides' attorneys, forensic physicians-averaged over $\$ 7,000$ per case in 1990; the average award for successful applicants was $\$ 11,879$.

113. Economist, 3 Oct. 1992, at 29. See also CWCI, Workers' Compensation Litigation Costs, 1990 (San Francisco: CWCI, Sept. 1991) ("CWCI, Costs"). In one case cited by reform groups, the claimant was a Sacramento workers compensation judge who smoked and drank heavily, suffered a stroke, and was then awarded a $\$ 45,000$ settlement under the compensation law after he claimed that his stroke was caused by job stress. Ralph Frammolino, "Claims for Stress Devour Billions, Reformers Charge," L.A. Times, 15 March 1988, at 3.

114. Herbert Kritzer, "The Politics of Redress: Controlling Access to the Court System in England" at 13, 16 (presented at Law \& Society Association annual meeting, 1993). 
During the late 1960s and 1970s, public interest law firms also lobbied hard and successfully, in legislatures as well as courts, to make adversarial legalism the primary mode of accountability in the expanding regulatorywelfare state. In his detailed analysis of the public interest movement, Michael McCann refers to "the judicial model of democracy" as one of the reformers' principal ideals.15 Public interest lawyers, McCann notes, wanted to expand governmental regulatory power, but they also were profoundly mistrustful of politicians and administrators, whom they viewed as inherently unresponsive or as corruptible by regulated businesses. The reformers' solution was to create an administrative process that would mimic the adversarial, formal, participatory procedures of courts-the one governmental institution they felt they could either trust or influence. The adversarial judicial model "defined for the new activists," McCann observes, "something like what the agora was for the Greeks, the tribunal was for the Romans, and the town meeting was for colonial New England citizen politics."116

Congress was indeed persuaded to build the ideal of adversarial legalism into the landmark regulatory statutes enacted in the 1960s and 1970s. Decision making in federal regulatory agencies, reformers successfully argued, should be constrained by procedural rules that $(a)$ guarantee participation by advocacy groups who might counter the atguments of regulated entities (thereby replicating in administrative agencies the court-house adversary model), and (b) compel administrative decision makers to provide rational, formal justifications for their actions (thereby replicating the judicial opinion as a method of accountability). ${ }^{117}$ To ensure compliance with these new administrative legal procedures, Congress broadened standing-tosue standards, enabling advocacy groups to challenge administrative decisions in the courts. In addition, Congress repeatedly enacted strict statutory deadlines for the achievement of regulatory objectives; the deadlines empowered advocacy groups to sue administrators who did not meet advocacy groups' enforcement priorities. ${ }^{118}$

How can we be sure these changes were "caused" by reform-oriented lawyers and their legal culture-rather than by political pressure from environmental, civil rights, and consumer groups, or from business interests who calculated that the institutions of adversarial legalism would protect them from zealous regulators? Without detailed studies of the evolution of particu-

115. Michael McCann, Taking Reform Seriously: Perspectives on Public Interest Liberalism 114 (Ithaca, N.Y.: Cornell University Press, 1986).

116. Id.

117. Id. at 112-13; Martin Shapiro, Who Guards the Guardians? Judicial Control of Administration (Athens: University of Georgia Press, 1988).

118. R. Shep Melnick, "Pollution Deadlines and the Coalition for Failure," in M. Greve \& F. Smith, eds, Environmental Politics: Public Costs, Private Rewards (New York: Greenwood Press, 1992) ("Greve \& Smith, Environmental Politics"). 
lar bills - and I have found few that focus on this issue ${ }^{119}$ - the precise role played by lawyer-staffers or lawyer-lobbyists remains unclear. It seems likely, however, that the ideals and lobbying efforts of "public interest movement" legal activists were a significant factor in "judicializing" policy-making and implementation in the new regulatory-welfare state-and in ensuring an ongoing, governmental role for public interest lawyers.

For example, according to a law school magazine, John Phillips, cofounder of the Center for Law in the Public Interest in Los Angeles, is "best known for his instrumental role in Congress in reviving and updating the False Claims Act in 1986."120 Congress passed the act in response to widespread publicity concerning wasteful expenditures in military procurement. The reform mechanism Congress adopted, however, relied more on adversarial legalism than on better top-down auditing. It empowered citizens to force a government investigation by filing a lawsuit, rewarding them with a bounty of $15 \%$ to $30 \%$ of any moneys recovered from contractors. Over 500 individual cases have been filed, resulting in $\$ 400$ million in recoveries to the U.S. Treasury. ${ }^{121}$ Consider, too, the 1980 federal Superfund statute, intended to clean up hazardous waste disposal sites. Unlike comparable regulatory programs in Western Europe, ${ }^{122}$ the Superfund Act reads as if it were designed by a plaintiffs personal injury lawyer. Its primary tool is the civil lawsuit. ${ }^{123}$ EPA enforcement officials are cast as tort lawyers, trying to maxi-

119. A noteworthy exception is Edward Rubin, "Legislative Methodology: Some Lessons from the Truth-in-Lending Act," $80 \mathrm{Geo}$. L. Rev. 233 (1991), which provides a detailed account of the formulation and drafting of the federal Truth-in-Lending Act. The act provided debtors a right of action against lenders who did not comply with the complex federal disclosure regulations, adding that prevailing plaintiffs would receive a $\$ 100$ minimum award, regardless of actual losses, plus their attorneys' fees. That was enough to enable many defaulting debtors, simply by hiring a lawyer and raising a Truth-in-Lending defense, to repel collection suits. And the $\$ 100$ remedy, "when combined with the procedural mechanism of class actions, raised the specter of enormous damages suits for minor violations of the statute" (id. at 237). According to Rubin's account, the private right of action enforcement mechanism arose not primarily from pressure by lawyer lobbyists but from Senator Douglas's hope of gaining political support for the bill by promising it would not require "spawning another federal bureaucracy" (id. at 246). But where did the idea of private enforcement, attorney fee shifting, and minimum damage awards come from?

120. Boalt Hall Transcript, Fall 1993, at 72, 85 .

121. Phillips is quoted as saying, "The law created unprecedented opportunities for private lawyers. What could be more exciting than being a quasi-public prosecutor of fraud, who, if successful, is paid handsomely for the job?" In 1992, Phillips's firm recovered $\$ 235$ million for the U.S. Treasury. Id.

122. Andrew Lohof, The Cleanup of Inactive Hazardous Waste Sites in Selected Industrialized Countries (Washington, D.C.: American Petroleum Institute, 1991); R. Kopp, P. Portney, \& D.DeWitt, "International Comparisons of Environmental Regulation" (Discussion Paper QE90-22-REV) (Washington, D.C.: Resources for the Future, 1990).

123. The Comprehensive Environmental Response, Compensation and Liability Act (CERCLA) imposes absolute, joint and several, and retroactive liability for clean-up costs on any enterprise whose wastes found their way into the disposal site-regardless of the disposer's share of the wastes, regardless of whether it acted perfectly lawfully under the legal rules and containment practices prevailing at the time of disposal, regardless of the absence of any demonstrated current harm to human health. 
mize dollar recovery by suing a few large corporate waste disposers, who then are compelled to sue other "potentially responsible parties" (PRPs). As Landy and Hague describe the result:

The potentially enormous costs confronting a firm caught within Superfund's liability net provide a powerful incentive to use every conceivable delaying tactic, either in the hope of finding some legal tool for wriggling free or for the purpose of dragging PRPs not identified by EPA into settlements. . . . Because of these dynamics, the shovels often remain in the tool shed while the EPA pursues PRPs along the slow and tortuous path of litigation. ${ }^{124}$

Superfund was not all lawyers' doing. It was supported by EPA, the hazardous waste treatment industry, and Congress members who could take a strong symbolic stand in favor of cleaning up sites in their districts without having to appropriate a lot of general funds revenues. ${ }^{125}$ But Superfund also reflects-indeed it virtually epitomizes-a legal culture that espouses adversarial legalism as mode of governance, and (although direct evidence is lacking) the fingerprints of legally trained legislators and staff members are all over it.

\section{Constructing Lawyers' Ethics}

In constructing rules of ethics for practitioners, a legal profession has a range of choices. It can stress the lawyer's duty to her client alone, zealously protecting and advocating the client's interests regardless of the costs or injustices to the rest of the world. Or legal ethics can enjoin attorneys to temper pursuit of clients' interests with concern for legitimate interests of third parties and society at large. The American legal profession long has stressed the ethic of zealous advocacy, in contrast to the legal professions of England and Western European nations, where "the ethical rules of conduct set greater limits on the lawyer's duty to protect client loyalty and confidentiality in deference to larger societal and third party

124. M. Landy \& M. Hague, "The Coalition for Waste: Private Interests and the Superfund," in Greve \& Smith, Environmental Politics (cited in note 118) ("Landy \& Hague, "Coalition for Waste"). Landy and Hague elaborate: "In an effort to clean up a site near Utica, New York, the EPA sued two companies-a cosmetics producer and a manufacturer of metal components-who, in turn, sued over 600 , mostly small, businesses and 41 towns and school districts." Not surprisingly, litigation and related transaction costs, governmental and private, add up to as much as $44 \%$ of the funds actually expended on clean-up. Peter Menell, "The Limitations of Legal Institutions for Addressing Environmental Risks," 5 J.Econ. Perspectives 93 (1991). And in consequence, the authors of a detailed study of Superfund implementation observe, "By mid-1990, . . after 10 years of program operation, only sixty-three of the more than twelve hundred National Priorities List sites had been cleaned up." T. Church \& R. Nakamura, Cleaning up the Mess: Implementation Strategies in Superfund (Washington, D.C.: Brookings Institution, 1993) ("Church and Nakamura, Cleaning up the Mess").

125. Landy \& Hague, "Coalition for Waste." 
interests." ${ }^{126}$ In recent years, the bar rebuffed efforts to temper American lawyers' obligations of loyalty and confidentiality vis-à-vis clients which engage in illegal behavior or fraud. ${ }^{127}$

Thus American lawyers have fought for rules of evidence that provide a broader and more absolute lawyer-client privilege than exists in most other countries. ${ }^{128}$ In contrast to most other legal professions, the American bar has endorsed contingency fees, justifying them on grounds that they facilitate litigation by the nonwealthy. American legal ethics endorse lawyers' practice of pretrial coaching of witnesses; German legal ethics strongly discourage it. ${ }^{129}$

The American legal profession's endorsement of the lawyer's duty of zealous advocacy - as opposed to her duty to serve as "officer of the court"encourages a more entrepreneurial form of legal practice than prevails in Europe. It authorizes lawyers to advance novel legal claims and arguments, challenging or stretching existing doctrine, and asserting that it is the court's job, not the lawyer's, to separate the wheat from the chaff. ${ }^{130}$

The adversarial ethic disseminated by the profession also has validated American trial lawyers' competition to develop ever more aggressive and costly techniques of litigation-dramatic "day-in-the-life" videos to illustrate the adverse effects of accidents; calculatedly burdensome pretrial discovery demands in high-stakes cases; extended voir dire of prospective jurors. Finally, the ethic of zealous advocacy encourages an aggressive style of lawyering that intensifies the practice of adversarial legalism within the bounds of existing legal rules and institutions-as elaborated more fully in the next section.

\section{CASE-BY-CASE LAWYERING AND ADVERSARIAL LEGALISM}

Most attorneys, sociolegal studies indicate, serve as stolid gatekeepers for the courts. Hence, most day-to-day, non-law-reform litigation, we can

126. Mark J. Osiel, "Lawyers as Monopolists and Entrepreneurs, Review of Lawyers in Society, edited by Richard L. Abel \& Philip P. C. S. Lewis (1988)," 103 Harv. L. Rev. 2009, 2019 (1990).

127. See Ted Schneyer, "Professionalism and Bar Politics: The Making of the Model Rules of Professional Conduct," 14 Law \& Soc. Inquiry 677 (1989).

128. Osiel, 103 Harv. L. Rev. at 2018.

129. Langbein, 52 U. Chi. L. Rev. 823, 833-34 (cited in note 6): "If we had deliberately set out to find a means of impairing the reliability of witness testimony, we could not have done much better than the existing system of having partisans prepare witnesses in advance of trial and examine and cross-examine them at trial."

130. Osiel, 103 Harv. L. Rev. at 2060, argues: "The stringency of their ethical guidelines on matters of client loyalty impelled American lawyers toward the imaginative discovery of doctrinal ambiguity where such ambiguity would otherwise have remained merely latent. In particular, the view of legal expertise as the skillful exploitation of doctrinal uncertainty would not have become so central to the self-understanding of American attorneys had their ethical guidelines encouraged them to view themselves, like many lawyers elsewhere in the West, primarily as 'officers' of society." 
safely assume, is stimulated not by lawyers but by clients or complainants. But surely that is not always the case. Suppose $10 \%$ or even $15 \%$ of legal contestation is the lawyer's idea-lawsuits filed or threatened in order to advance lawyers' pecuniary interests or to vindicate ideals they hold dear. Surely, $10 \%$ or $15 \%$ more (or less) legal contestation is not an insignificant matter.

Well, how much legal contestation is lawyer-induced (as opposed to client-induced)? 10\%? 15\%? 20\%? 2\%? We don't know. Legal and sociolegal scholars have had little to say on the subject, perhaps for fear of providing support to conservative lawyer bashers. But a great deal of anecdotal evidence, and limited systematic evidence, suggests that there is a significant amount of what we might call superaggressive lawyering, exacerbating the costs and delays of "adversarial legalism as practice." Quantitative measures are elusive. This section offers a selective description of several subspecies of superaggressive lawyering, none of which dominate the legal rain forest, but which also do not appear to be on the endangered list.

\section{A. Ambulance Chasers}

Big Yank Corporation's sales of work clothing fell from $\$ 110$ million in 1991 to $\$ 65$ million in 1992 . After the company told the 225 workers in its Wewoka, Oklahoma, factory that the money-losing plant would be closed, a representative of a workers compensation law firm met with employees, according to company officials, distributed forms, and told them how to file claims. Two days before the plant closing, 247 claims for work-related injuries were filed-compared to 6 for that factory in the previous year. Much litigation ensued, both between Big Yank's insurer and workers whose claims it disputed, and between the insurer and Big Yank, which claimed the insurance company had been lax in challenging fraudulent claims. ${ }^{131}$

In the United States, severance pay and unemployment benefits are quite limited when compared to western European welfare states. American workers' motivation to use injury claims to help alleviate economic hardship thus stems from a structural problem-the political weakness of American organized labor and the porousness of protective labor legislation. But workers' vulnerability does not automatically generate legal injury claims. Statewide studies suggest that as in Wewoka, sudden surges in workers compensation claims, many of them legally questionable, occur quite regularly when factories close, ${ }^{132}$ indicating that in those situations workers compensation lauyers, or some of them, play a causal role. C7.

131. Peter Kerr, "The High Cost of Job Injury Claims," N.Y. Times, 22 Feb. 1993, at C1,

132. Id. 
Some lawyers almost literally chase ambulances. They send runners to hospitals and union halls to give the attorney's cards to injured people. Others send representatives to the scene of highly publicized train wrecks, chemical spills, and explosions, or seek out individuals who have had some exposure to harmful substances. Aided by modern technologies and communications systems, and motivated by the far higher damage awards attainable in serious injury cases, contemporary ambulance chasers almost certainly far overshadow the efforts of their counterparts earlier in this century. ${ }^{133}$

Some people in ambulances, of course, have valid cases. Nevertheless, ambulance chasers actively turn injuries into legal claims, which incrementally adds to the wider culture's acceptance of litigation as an appropriate social response. ${ }^{134}$ To be sure, most injured persons never hire an attorney. ${ }^{135}$ And it seems unlikely that more than a small proportion of those who do bring suit were first encouraged to do so by the lawyer or his agents. But anecdotes about ambulance chasing suggest that it is not rare. Moreover, there seem to be particularly "claims conscious" subcultures in which especially aggressive lawyers play a prominent role. ${ }^{136}$ Some systematic research on the topic seems long overdue.

133. In 1986 two lawyers formed the National Tire Workers Litigation Project, equipped vans with $\mathrm{x}$-ray machines, traveled to tire plants offering examinations of workers who had been exposed to asbestos, and filed suit on behalf of 6,000 workers. A federal trial judge accused the attorneys of "indifference as to whether any of the 6000 claims meet professional standards or not." M. Geyelin \& M. McCarthy, "Judges Chides Lawyers Facing Suit for Thousands of Asbestos Claims," Wall St. J., 7 June 1990, at B8. For other examples, see M. Geyelin, "Texas Lawyers Seek Bill to Curb Their Soliciting," Wall St. J., 25 May 1993, at B1. Conversely, it should be noted, insurance companies long have dispatched representatives to disaster scenes in order to make quick payments to victims, asking for releases in return.

134. For an analysis of survey evidence indicating that Americans are more likely to blame others for accidents than the English, and more likely to make legal claims for compensation-even when the injured person thinks he or she is partly at fault, see Herbert Kritzer, "Propensity to Sue in England and the United States of America: Blaming and Claiming in Tort Cases," 18 J. Law \& Soc'y 400 (1991).

135. Deborah Hensler et al, Accidents and Injuries in the U.S.: Costs, Compensation, and Claiming Behavior (Santa Monica, Cal.: RAND Institute for Civil Justice, 1991); R. Miller \& A. Sarat, "Grievances, Claims and Disputes: Assessing the Adversary Culture," 15 Law \& Soc'y Rev. 525 (1980-81).

136. I have interviewed a number of claims officials who work for West Coast shipping lines and handle claims under the federal Longshore and Harbor Workers Compensation Act. I am invariably told that claims rates are far higher in the Ports of Los Angeles and Long Beach than for essentially identical stevedoring operations in the Ports of Oakland and San Francisco. The employers contest a far larger proportion of claims in the Los Angeles ports as unfounded or inflated. Asked why, they refer to the entrepreneurial behavior of claimants attorneys whose offices abut the port area on San Pedro Bay and who station representatives in union halls.

One suspects aggressive attorney behavior is involved when research reveals that in Southern California, workers compensation insurers' or employer's first notice of injury claims came from the claimant's attorney in almost $55 \%$ of 1991 claims, up from $44 \%$ in 1985 , while attorneys were initially engaged in only $29 \%$ of 1991 Northern California claims, a decline from $34 \%$ in 1985 . Similarly, workers compensation litigation rates (an indicator of how often insurers find claims unfounded or exaggerated) rose from $10 \%$ of Southern California claims (1985) to $17.5 \%$ (1991), while litigation occurred in only $8.2 \%$ of Northern California 1991 claims. CWCI, Costs (cited in note 113). 
Aggressive advertising by lawyers, a practice only about 10 or 15 years old, might be considered a subspecies of ambulance chasing. A Boston lawyer advertises on the radio about the potential for filing lawsuits against landlords for exposure to lead paint. ${ }^{137}$ Annual TV advertising expenditures by lawyers, the Television Bureau of Advertising reports, grew from about $\$ 17$ million in 1983 to over $\$ 100$ million in $1991 .{ }^{138}$ A televised ad shown in Florida portrayed a boy squirming in a barber's chair. "If you don't stop moving, Jonathan, I'll cut your ear off," says the barber. The boy spins his chair and replies, "Yeah, and if you do, I'll call attorney David Singer." Singer then appears on screen to intone, "No client is too small to benefit from our legal protection."139 Of course, much lawyer advertising is not tasteless. Much of it may convey useful information about access to justice. Perhaps most people who respond to an ad eventually would have found a lawyer in other ways. Nevertheless, lawyers who advertise probably can be thought of as reinforcing and legitimizing a culture of adversarial legalism and as helping, by the power of suggestion, to turn into lawsuits some grievances that might have been dealt with otherwise. Here, too, systematic research might be illuminating.

\section{B. Entrepreneurial Class Actions}

In 1990, a New York law firm filed a state court class action against seven major brokerage houses on behalf of all investors-a class of about 1 million-who held margin accounts between 1984 and 1990. The suit claimed that the brokerage houses illegally charged compound interest-on

New York City's municipal liability payments for slip-and-fall accidents in 1991, calculated on a per capita basis, were double those in Detroit and more than $50 \%$ higher than Chicago's. The city's aggregate liability claim payments grew by almost $50 \%$ in the preceding three years, until they exceeded what the city pays to operate all its parks and libraries. The city's attorneys, according to a New York Times reporter, "attribute their rising expenses to increasingly litigious citizens, zealous (and sometimes fraudulent) trial lawyers, and juries often ruled more by emotions than facts." They claim that "lawyers whose clients are injured in car accidents or sidewalk stumbles scrutinize the pavement for defects that can drag the city into the case. Even if the jury finds that the city is just 5 percent at fault, in the absence of other wealthy defendants, the city can be held responsible for . . . damages." Allen Myerson, "Soaring Liability Payments Burden New York's Budget," N.Y. Times, 29 June 1992, at A15.

137. David Stipp, "Dogma in Doubt: Some Question Extent of Lead's Risk to Kids, Need to Remove Paint," Wall St. J., 16 Sept. 1993, at A1, A12. The Boston attorney told a reporter that he had filed hundreds of lead poisoning suits, including one in which he won a $\$ 9,000$ settlement for the mother of a child who had a tested lead level of zero. "As asbestos litigation dries up," he was quoted as saying, "law firms geared up for toxic tort litigation are turning to lead."

138. Milo Geyelin, "Debate Intensifies over State Regulations that Restrict TV Advertising by Lawyers," Wall St. J., 31 Aug. 1992, at B1.

139. Id. Another Florida TV ad featured a man who said that after his third arrest for drunk driving, "They wanted to put me in jail for a year and take away my drivers license for 10 years. That's when I called the lawyers at the Ticker Clinic. They got my case thrown out of court. No jail. No suspension. Nothing." Id. 
the credit they extended and on accumulated unpaid interest. According to a newspaper account:

The brokers countered that the interest rate charges on margin accounts, which are applied in a similar manner to those of credit cards, are part of a long-standing policy well understood by their customers. In addition, they said it was completely lawful.

Thousands of hours of legal work later, the lawyers for both sides agreed to settle the suit without any resolution of the legal issues involved. (In fact, the New York Legislature recently clarified state law to make it clear that compounding interest on margin accounts is legal.) The defendants agreed to notify customers about the compound interest rates . . . and to pay legal fees to the plaintiffs' attorneys. ${ }^{140}$

A spokesman for defendant Merrill Lynch \& Co. said the company has long included a notice to margin customers about interest charges but that it agreed to pay a portion of plaintiffs' legal fees, which totaled $\$ 1$ million, in order to avoid further litigation expenses. ${ }^{141}$

After learning of a government investigation of alleged price fixing by major airlines, attorneys filed 21 cases on behalf of 12 million passengers. After three years, the consolidated cases were settled for $\$ 458$ million in cash and discount coupons, and $\$ 14.4$ million in fees for the plaintiffs' lawyers-even though, according to a Wall Street Journal account, ${ }^{142}$ the presiding judge said he "would assess the chances of the plaintiffs recovering as not good" and that "I think the case would have a hard time surviving a motion for summary judgment." But it made sense for the defendants to settle once they hit on the idea of paying the actual plaintiffs in discount coupons (worth $10 \%$ off purchased tickets for off-peak travel). Again, the plaintiffs' attorneys got a big payoff while providing their "clients"- those who bother to go to the trouble of proving they fall within the affected class and collect the coupons-with minimal benefits.

In these cases opportunistic lawyers themselves initiated litigation and used the club of costly adversarial legalism to extract settlements that primarily benefited the lawyers themselves. Are these isolated stories, or are they commonplace? Apparently the latter, as indicated by these studies:

- Janet Cooper Alexander found that in 1983, a handful of entrepreneurial California law firms routinely filed a class action suit against every computer company, nine in all, whose stock declined substantially in the half-year following its initial stock offering. ${ }^{143}$

140. Jonathan M. Moses, "Accord Enriching Only Lawyers Assailed," Wall St. J., 23 Jan. 1992, at B8.

141. Id.

142. "Crass Action," Wall St. J., 1 April 1993, at A14.

143. Janet Cooper Alexander, "Do the Merits Really Matter? A Study of Settlements in Securities Class Actions," 43 Stan. L. Rev. 497, 513 (1991). The suits were filed whenever a 
Regardless of the apparent strength (or weakness) of the claim, defendants felt compelled to settle the case on the eve of trial for about $25 \%$ of the potential damages. Why? Because, Alexander says, the potential damages claimed were "astronomically high"; "insurance and indemnification rules ... make substantial sums of money ... available for negotiated settlements but not for judgments after trial"; and the rules for paying plaintiff lawyers' counsel fees made it very advantageous for them-if not for the class of investors they putatively represent-to settle before trial (but after conducting a vigorous round of pretrial discovery). ${ }^{144}$ The plaintiffs lawyers ended up with fees of $\$ 2-\$ 3$ million (averaging $27 \%$ of the recovery), defendants' lawyers with even more, and most of the "damages" (averaging $\$ 9$ million) did not go to small investors but served to "insure a relatively small number of institutional investors against market losses from a speculative investment." 145 Moreover, the resulting "non-merits-based settlement regime also encourages the filing of more and weaker suits." 146

- Roberta Romano, in an equally brilliant study of a broader population $(n=139)$ of shareholder suits, ${ }^{147}$ also found that the settlement pattern is consistent with the proposition "that a significant proportion of shareholder suits are without merit"; 148 that the litigation did not produce significant structural changes in board composition ${ }^{149}$ or other changes in corporate governance; and "that the principal beneficiaries of cash payouts in shareholder suits are attorneys."150

- Large pretrial settlements (and lawyers' fees) have been paid in many "toxic tort" class actions, sometimes even in the absence of proof of harm to human health stemming from the chemical expo-

stock sustained a market loss of $\$ 20$ million or more, skipping some smaller issues in which some larger percentage losses occurred, since that amount seems to have been necessary to make the contingency fee litigation profitable. The plaintiffs' lawyers clearly filed suit merely on the basis of the stock decline, without any prior evidence of fraud or other securities laws violations, and then sought detailed pretrial discovery that probed for evidence that management had in some way exaggerated the company's product quality or sales prospects. See also L. Fisher, "Williams S. Lerach: The Pit Bull of Silicon Valley," N.Y. Times, 19 Sept. 1993, sec. F, at 4; A. Serwer, What To Do about Legal Blackmail," Fortune, 15 Nov. 1993, at 136-40.

144. Alexander, 43 Stan. L. Rev. at 499.

145. Id. at 575 .

146. Id. at 501.

147. Roberta Romano, "The Shareholder Suit: Litigation without Foundation?" 7 J.L., Econ. \& Organization 55 (1991). Romano studied all shareholder suits against a random sample of publicly traded corporations from the late 1960 s through 1987.

148. Id. at 61.

149. "A likely explanation for cosmetic structural settlements is the need to paper a record to justify an award of attorneys' fees to courts." Id. at 63.

150. Id. at 65 . Of the 83 resolved cases in Romano's sample, only half involved a monetary recovery for stockholders, while plaintiffs' attorneys were paid in $90 \%$ ( 75 cases), and in 7 cases the only relief was attorneys' fees. Of the 32 adjudicated cases, plaintiffs won only one (or perhaps two). Id. at 61 . 
sures in question, largely because corporate defendants face enormous "bet your company" potential damages. ${ }^{151}$

- A study of federal class actions in the Northern District of California, 1979-84-as I read the account-found that in most cases, plaintiffs' substantive justice claims-if there were any real plaintiffs not recruited by the law firm that brought the class action-were transformed into narrow procedural issues about notice and rights to be heard, providing few significant results for anyone except the lawyers. ${ }^{152}$

Undoubtedly some class actions are socially useful, punishing and hence deterring unlawful corporate behavior. But quite often, it seems, the lawyers who claim to serve as "private attorneys general" really only "pile on" after the government has imposed criminal sanctions. ${ }^{153}$

\section{Ideological Ambulance Chasers}

Some lawyers seek out lawsuits for political motives. The raison d'être of many public interest law firms is to use litigation to protect particular values or group interests. They chase not ambulances but perceived instances of governmental and corporate misconduct. They are legal knightserrant, looking for the dragon of authority to sue, whether or not called into action by any particular damsel in distress. Thus the American Civil Liberties Union monitors governmental processes for perceived violations of free speech, freedom of religion, due process and other values, whether or not the organization's help has been sought by a client; the lawsuit and the appeal are its primary methods of exerting leverage. Natural Resources De-

151. M. Peterson \& M. Selvin, "Mass Justice: The Limited and Unlimited Power of Courts," 54 Law \& Contemp. Probs. 227, 227, 231, 241 (1991); Peter H. Schuck, Agent OTange on Trial: Mass Toxic Disasters in the Courts (Cambridge, Mass.: Belknap Press, 1986); Peter Huber, "Environmental Hazards and Liability Law," in R. Litan \& C. Winston, eds., Liability: Perspectives and Policy (Washington, D.C.: Brookings Institution, 1988).

152. Bryant Garth, "Power and Legal Artifice: The Federal Class Action," 26 Law \& Soc'y Rev. 237, 257 (1992): "Turning to the benefits provided to the class, the facts do not add up to a strong picture of litigation than makes lasting improvements in the lives of class members."

153. A study of private class actions based on insider trading offenses found that virtually all piggybacked on investigations or charges first brought by the Securities and Exchange Commission. Thomas Hetherington, "When the Sleeper Wakes: Reflections on Corporate Governance and Shareholder Rights," 8 Hofstra L. Rev. 183 (1979). In the antitrust context, John C. Coffee, Jr., "No Soul to Damn, No Body to Kick: An Unscandalized Inquiry into the Problem of Corporate Punishment," 79 Mich. L. Rev. 386, 435 (1981), observes:

The private plaintiff is typically a "free rider" who files his civil action in the wake of an indictment brought by the Antitrust Division. It is not uncommon today for the private enforcer to attend the criminal trial and to take copious notes so that evidence uncovered by the government will yield a treble damage recovery for him. . . . In such cases, the actual litigation undertaken by the private enforcers is chiefly internecine: they skirmish among themselves over such procedural issues as the appointment of lead counsel, the size of the settlement, and the allocation of attorney's fees. 
fense Council lawyers scour the compliance reports that permit holders must file with the EPA pursuant to the Clean Water Act; from these reports, they target self-reported violators whom they then sue for damages. ${ }^{154}$

Public interest law firms are run by lawyers who are admired by many law students precisely because they proactively pursue justice through litigation. Public interest lawyers add deterrent punch to public law, defend individuals and values that otherwise would lack representation, and enhance accountability of governmental bodies. Their technique, however, is aggressive, sometimes unsolicited litigation; hence they "independently" add to adversarial legalism in the United States.

\section{Legal Extortionists and Warrior Litigators}

As the story is told by journalist James B. Stewart, George Kern, Jr., a senior partner in Sullivan \& Cromwell, "wasn't entirely satisfied with his defensive legal efforts" to prevent a hostile takeover of his client, the giant Kennecott Copper corporation, by T. Roland Berner, a lawyer who was chairman of Curtiss-Wright Corporation. Kern "began a plan which would put Kennecott on the offensive-and silence Berner as a threat forever." 155 The plan included a lawsuit designed to block Curtiss-Wright's tender offer, on far-fetched antitrust grounds, as well as Kennecott's own hostile takeover of Curtiss-Wright-which Curtiss-Wright's lawyers attempted to block by a separate series of lawsuits. There followed a furious round of additional legal actions, requests for ex parte injunctions, countersuits, motions, and appeals, scattered through several jurisdictions. None of the legal claims or arguments concerned a fundamental issue-such as whether a Curtiss-Wright takeover over Kennecott (or vice versa) would be good or bad for Kennecott shareholders, or for the copper industry, or for the national economy. All the litigation was designed simply to slow down or derail the other corporation's tender offers. Finally, the two companies, exhausted by the legal struggle, agreed to settle without either taking over the other. Kennecott had expended $\$ 1.5$ million in legal fees. "In the end," Stewart concludes, "little was accomplished."156

In this struggle, top attorneys deployed groups of younger lawyers like panzer divisions. The purpose of the litigation was to create obstacles and impose costs, not to vindicate their clients' deeply felt legal rights. To para-

154. A 1984 study showed that 349 notices of intent to sue were filed under federal pollution control laws in the 1978-April 1984 period, 214 of which were filed under the Clean Water Act after 1982, most by environmental groups. An article published in 1989 found that more than 800 additional notices of intent to sue were filed after April 1984, twothirds by environmental organizations. Greve, 97 Pub. Interest at 18 (cited in note 104).

155. James B. Stewart, The Partners: Inside America's Most Powerful Law Firms 146 (New York: Simon \& Schuster, 1983).

156. Id. at 282. 
phrase Mae West, justice had nothin' to do with it. Although Stewart's account, based on interviews with lawyers, may downplay the role of the clients, it is plausible to believe that in these legal maneuverings, the lawyers devised the strategies. They deliberately searched the law and its procedures for any available charge or defense, manipulating the techniques of adversarial legalism for ends not contemplated by the lawmakers.

How often does such manipulative use of the legal system-or what sometimes is called "strategic litigation"-occur? It surely does not characterize most commercial and financial litigation. But it is not uncommon. Gilson states, "Familiar examples of strategic litigation include knee-jerk defensive litigation in response to hostile takeovers and trade secret suits brought against departing employees to chill their new business's access to venture capital."157 Extortive, obstructionist, and intimidative litigation can be found in many spheres of practice. For example:

- Canan and Pring systematically studied SLAPP suits-"strategic lawsuits against public participation."158 Their search of legal libraries and trial court records, along with a mail questionnaire to public interest organizations, turned up 100 damage suits (mostly for defamation) filed against citizen protestors and critical advocacy groups, by lawyers for real estate developers, city government officials, public utilities, police officers, and alleged polluters. Parents were sued by a board of education for complaining about allegedly unsafe school buses. Homeowners who sponsored a referendum petition to block a proposed project were sued by the real estate developer. Police officers sued those who complained of official misbehavior. Canan and Pring conclude from the fact that most of these suits seek high money damages, rather than injunctive relief, that the goal was primarily to impose high litigation costs and hence silence critics. And their finding that final legal judgments favored the citizen-defendants in $80 \%$ of the SLAPP suits that reached a legal disposition suggests that lawyers for the SLAPPers not only were ineffective gatekeepers for the courts but willingly participated in the use of legal processes for purposes of intimidation.

- Opponents of development, too, use lawsuits as obstructive or extortive tactics in a struggle to attain other ends. Some advocacy groups and their lawyers are inclined to oppose highway construction, logging, waste incinerators, or offshore oil development on principle. The lawsuits they bring, however, often are cast far more narrowly, as challenges to the completeness of environmental impact statements. The best legally obtainable result, in many cases, would be

157. Gilson, 17 Law $\mathcal{\&}$ Soc. Inquiry at 639 (cited in note 50). See also Cheit, 11 Stud. L., Pol. \& Soc'y (cited in note 34).

158. P. Canan \& G. Pring, "Studying Strategic Lawsuits against Public Participation," 22 Law \& Soc'y Rev. 385 (1988). 
not to stop the project but to compel additional analysis and a rewriting of the EIS. ${ }^{159}$ The purpose of the litigation is the hope, often not unfounded, that the delays and costs imposed by the lawsuit, along with related opportunity costs, will compel the developers or public agencies to abandon the project altogether. ${ }^{160}$

- Attorneys opposed in principle to the death penalty deliberately exploit every possible opportunity to file multiple state and federal appeals and habeas corpus petitions, often on legal grounds highly unlikely to succeed, in hopes that the extraordinary delays, the build-up of prison death row populations, or the publicity attending frantic last-minute appeals will increase political pressures for clemency or for legal change. To many who oppose capital punishment, the defense lawyers' actions are morally justifiable and even commendable. But it is hard to deny that many death penalty appeals, typically stretching out for years, represent a manipulative form of adversarial legalism, devised and extended by lawyers. ${ }^{161}$

\section{Unwarranted Claims and Defenses}

In a publication of the national association of law school job placement officials, an Atlanta attorney wrote:

As a litigator, I see lots of cases filed now that no self-respecting lawyer would have taken 15 years ago. The plaintiff's attorney has the high costs of litigation as leverage and can reasonably hope for a nuisance or moderate settlement from the defendant who doesn't want to pay his or her lawyers an arm and a leg to defend the action. ... And if you think that a manufacturer against whom an absolutely baseless products suit is brought will surely escape on summary judgement . . . and maybe even recover expenses and attorneys' fees because of the frivolous nature of the suit, you are naive. ${ }^{162}$

159. See Serge Taylor, Making Bureaucracies Think: The Environmental Impact Statement Strategy of Administrative Reform 240-48 (Palo Alto, Cal.: Stanford University Press, 1984).

160. M. O'Hare, L. Bacow, \& D. Sanderson, Facility Siting and Public Opposition (New York: Van Nostrand, 1983); Charles Lester, "The Search for Dialogue in the Administrative State: The Politics, Policy, and Law of Offshore Oil Development" (Ph.D. diss., University of California, Berkeley, 1991).

161. It should be emphasized, of course, that criminal defense lawyers' aggressive use of the mechanisms of adversarial legalism is wholly justified whenever there is any reasonable doubt of guilt. It is especially justified in capital cases and others in which prosecutors may be under political pressure to obtain a conviction. See Peter Applebome, "On the Fast Track from the Courtroom to Death Row," N.Y. Times, 7 March 1994, sec. 4, at 2.

162. W. Seaborn Jones, "Mothers, Don't Let Your Children Grow up to Be Lawyers," in National Association for Law Placement, Report to Law School Deans and Hiring Attomeys on Legal Employment (Washington, D.C.: the Association, 1993). 
Is there any systematic evidence to back this up? Some studies suggest that a significant number of plaintiffs' lawyers do a relatively poor gatekeeping job:

- The Administrative Office of the U.S. Courts estimates that more than one in three (35\%) civil cases are disposed of by motion to dismiss or motion for summary judgment. ${ }^{163}$

- The Wisconsin Civil Litigation Project found that $22.5 \%$ of civil suits were dismissed or adjudicated on the merits before trial. ${ }^{164}$

- Rule 11 of the Federal Rules of Civil Procedure provides for sanctions against attorneys for filing frivolous or dilatory pleadings or motions. In a survey of 4,500 attorneys who had litigated federal cases, $24.3 \%$ said that they had been involved in cases during the preceding 12 months in which motions or show cause orders for imposition of Rule 11 sanctions had been filed, and $7.5 \%$ had been in cases in which sanctions had been imposed. More than half had been involved in cases in which a Rule 11 motion had been filed or threatened. ${ }^{165}$

- Competent plaintiffs' counsel presumably would not initiate or would settle claims in which the prospect of winning at trial was significantly lower than $50 \% .{ }^{166}$ Thus using records from federal district courts for 1978-85, Eisenberg found that plaintiffs in most kinds of contract cases (in which damages are generally limited to out-of-pocket losses) won at trial more than $60 \%$ of the time $(n>\$ 10,000) .{ }^{167}$ They also won $60 \%$ of motor vehicle accident personal injury trials $(n=3,261)$ and $46 \%$ of "other personal injury" trials. But plaintiffs won only $33 \%$ of trials in motor vehicle product liability cases $(n=392)$, only $25 \%$ of other product liability trials

163. Of course, judges may sometimes dismiss valid suits or defenses by improvidently granting motions for summary judgment. But it is likely that judges even more often fail to grant summary judgment motions when there are persuasive reasons to do so. Judith Resnick, "Failing Faith: Adjudicatory Procedure in Decline," 53 U. Chi. L. Rev. 494 (1986). If that is so, then the $35 \%$ figure understates the number of legally unfounded cases or defenses.

164. David Trubek et al., "The Costs of Ordinary Litigation," 31 UCLA L. Rev. 72 (1983). Similarly, a study of medical malpractice claims filed in Florida concerning birth injuries found that $30 \%$ were closed with no payment. F. Sloan \& S. Van Wert, "Cost and Compensation of Injuries in Medical Malpractice," 54 Law \& Contemp. Probs. 131, 155 (1991).

165. Here, too, the measure is imperfect. On one hand, Rule 11 motions sometimes are filed for strategic reasons, which weakens the claim that they can be used as a proxy for unfounded claims and defenses. On the other hand, judges are notoriously reluctant to grant such motions, partly because of a legal tradition that favors zealous advocacy and innovative legal arguments. Still, it is interesting that more than half the litigators surveyed had been involved in recent cases in which lawyers felt impelled to make or threaten a motion claiming the other side was abusing the legal process. L. Marshall, H. Kritzer, \& F. Zemans, "Public Policy: The Use and Impact of Rule 11," 86 Nw. U.L. Rev. 943 (1992). (1984).

166. G. Priest \& B. Klein, "The Selection of Disputes for Litigation," 13 J. Legal Stud. 1

167. Theodore Eisenberg, "Testing the Selection Effect: A New Theoretical Framework with Empirical Tests," 19 J. Legal Stud. 337 (1990). 
( $n=3255$ ), and $38 \%$ of personal injury cases based on medical malpractice ( $n=697$ ). This suggests that in contingency fee cases with potentially large money damages, many plaintiffs' lawyers are willing to push defendants to trial in cases in which liability is questionable; the chance of a big payoff makes it worthwhile for them to try some "long shots." 168

Parallel deficiencies in gatekeeping occur on the defense side. In a study of litigation in the Southern District of New York, William Nelson found that contract cases tripled between the 1960s and the 1973-79 period, and that the percentage of cases in which a party was represented by a major corporate law firm increased by $40 \%$. Nelson argues that the increase in intercorporate litigation stemmed primarily from structural changes in the economy, in regulatory regimes, and in corporate management, all of which affected corporate executives' incentives. But he also asserts: "Litigation was also promoted during the 1970 s by the willingness of lawyers to provide managers with opinion letters or other advice that nonperformance of a contract followed by litigation was a legally appropriate course." 169 Corporate lawyers, Nelson suggests, were willing to suggest to managers (or endorse managers' suggestions) that even in the absence of a strong legal argument for contractual nonperformance, it might be both economically advantageous and morally acceptable to wait and be sued-since in a clogged, costly court system, the plaintiff might settle for far less than its legal due. ${ }^{170}$

\section{Pretrial Discovery Abuse}

Second Circuit Court of Appeals Judge Ralph K. Winter, who also served as a member of the federal courts' Advisory Committee on Civil Rules, wrote:

In private conversations with lawyers and judges, I find precious few ready to argue that pretrial discovery involves less than considerable to

168. See also Thomas Metzloff, "Resolving Malpractice Disputes: Imaging the Jury's Shadow," 54 Law \& Contemp. Probs. 43, 45, 77-79 (1991) (in malpractice cases with contested liability, plaintiffs' win rate only slightly over $10 \%) ; \mathrm{R}$. Bovberg, F. Sloan, \& C. R. Shieh, "Juries and Justice: Are Malpractice and Other Personal Injuries Created Equal?" 54 Law \& Contemp. Probs. 5, 36-38 (1991) (plaintiffs win malpractice verdicts only half as often as in auto accident cases).

169. William Nelson, "Contract Litigation and the Elite Bar in New York City, 1960-1980," 39 Emory L. Rev. 441, 446 (1990).

170. Nelson provides litrle supportive evidence concerning this alleged shift in the legal ethics of corporate law firms. But neither is it implausible, especially in an era in which large law firms had to compete ever more fiercely to maintain their litigation departments and the growth in billings on which they had become dependent. See M. Galanter \& T. Palay, Tournament of Lawyers: The Transformation of the Big Law Firms (Chicago: University of Chicago Press, 1991). 
enormous waste. ... [The Advisory Committee found] a no-stone-leftunturned ... philosophy of discovery governs much litigation and imposes costs, usually without corresponding benefits. . . . Second, discovery is sometimes used as a club against the other party . . . solely to increase the adversary's expenses. ${ }^{171}$

Of course, this doesn't occur in every case, or even in the average one, where the monetary stakes are not very large. ${ }^{172}$ But it clearly happens a great deal in high-stakes cases. To many litigators, like legendary Coach Vince Lombardi, winning is the only thing, and discovery demands and other pretrial maneuverings become a technique for grinding down the opposition. Thus Professor Robert Rabin, a judicious moderate on tort reform and reporter to an $\mathrm{ABA}$ commission on the liability system, concluded:

The ... most troublesome aspect of the spiralling costs of the system is not excessive litigation per se but too much lawyering-more concretely, the tendency to abuse the torts process through strategic resort to delay and imposition of burdensome costs of trial preparation. The many forms of this abuse include spurious motions practice, excessive deposition taking, unnecessary continuances, frivolous claims, and multiple lawyering. ${ }^{173}$

Chicago lawyers who often are involved in large-stakes litigation admitted to a researcher that they often (i.e., in $40 \%$ of their cases or more) had used discovery tools simply to impose work burdens or economic pressure on their adversaries. The lawyers also said they often made discovery demands or delayed responses to discovery in order to slow down an action; bombarded the other side with huge amounts of information as a way of obscuring crucial information; and tutored witnesses to give evasive answers in depositions. ${ }^{174}$

Trial practice is not much better. Trial attorneys-not all, but manyroutinely endeavor to prevent the introduction of unfavorable facts, attack the credibility of adverse witnesses by exaggerating small inconsistencies,

171. Ralph K. Winter, "Foreword: In Defense of Discovery Reform," 58 Brooklyn L. Rev. 263, 264 (1992).

172. In a careful study of litigation in both state and federal courts in 1978, researchers associated with the Wisconsin Civil Litigation Project found that most civil cases-only some $12 \%$ of which involved claims of $\$ 50,000$ or more-settled relatively quickly and hence in over half the case files there was no record of any pretrial discovery. And "rarely did the records reveal more than five separate discovery events." Trubek et al., 31 UCLA L. Rev. 72 (1983) (cited in note 163).

173. Robert L. Rabin, "Some Reflections on the Process of Tort Reform," 25 San Diego L. Rev. 13, 42 (1988).

174. Wayne Brazil, "Views from the Front Lines: Observations by Chicago Lawyers about the System of Civil Discovery," 1980 A.B.F. Res. J. 219. For all the admitted waste in the discovery process, it is often ineffective. Large-case litigators estimated that $50 \%$ of their cases are closed out with at least one party believing it knows something of significance that opposing parties do not know. 
and engage a variety of obstructionist tactics. ${ }^{175}$ Many lawyers transform a system of pretrial pleadings designed to foster nontechnical, nonadversarial behavior into patterns of obfuscation and costly motion practice. ${ }^{176}$ If the reader's response is "Of course!" that only shows the extent to which lawyers have propagated a legal culture that leads us to accept "excessive" adversarial legalism as normal.

\section{Criminal Defense and Prosecution}

Attorneys representing poor or near-poor criminal defendants, it is commonly observed, often fail to mount aggressive legal defenses. Sometimes there is too little adversarial legalism. But in some stages of the proceedings and in some kinds of cases, intensely adversarial, even obstructive litigation tactics are very common. Indeed, they are encouraged by the conventional interpretations of the defense attorney's proper role. Criminal lawyers routinely tell suspects never, never to say anything to investigators. They treat the right to silence as an obligation, thereby encouraging offenders to adopt an adversarial rather than a cooperative or repentant stance-at least until the attorney is able to use that silence to try to extort a reduced sentence. Once the possibility of a criminal investigation arises, corporate defense lawyers routinely try to prevent corporate officers and employees from speaking with regulatory officials. ${ }^{177}$ Some criminal defense lawyers as a matter of course bring unwinnable motions to suppress evidence, ${ }^{178}$ deliberately imposing unnecessary delays or costs on the prosecution.

Politically ambitious or competitive public prosecutors, too, often seem to put winning high visibility cases ahead of the pursuit of justice. For example:

- Brill describes two cases in which prosecuting attorneys in the offices of the U.S. Attorney for the Southern District of New York and for the Securities and Exchange Commission, respectively, manipulated legal rules, and probably misrepresented key facts, in

175. Michael J. Kaufman, "The Role of Lawyers in Civil Litigation: Obstructors rather than Facilitators of Justice," Ill. B.J., Dec. 1988, at 202, 203.

176. Rule 9(b) of the Federal Rules is designed to avoid unnecessary contentiousness by requiring plaintiffs to state claims of fraud "with particularity." But according to Kaufman (id.), "One would be hard-pressed to envision a lawsuit with common law fraud, securities fraud or RICO claims that did not get bogged down in a Rule 9(b) dispute" because the plaintiffs lawyer, unwilling to help the defendant prepare, "typically resists the nonadversarial spirit of Rule 9 (b) by alleging fraud in a general notice-pleading manner."

177. Bernard Penner, "The Prosecutor and Ex Parte Communications," Nat'l Envtl. Enforcement J., May 1992, at 3; Kenneth Mann, Defending White Collar Crime (New Haven, Conn.: Yale University Press, 1985).

178. In a study of several criminal courts, Peter Nardulli, "The Societal Costs of the Exclusionary Rule Revisited," 1987 U. Ill. L. Rev. 223, found that only 17\% of motions to suppress physical evidence were granted, and only $5 \%$ of motions to suppress confessions. In Chicago, while motions to suppress were more often granted at pretrial hearing, those made before the trial court were granted only $12 \%$ of the time. 
order to steer two closely watched prosecutions-one against the Teamsters, one against Drexel Burnham-onto the dockets of federal judges who were well known to be biased in favor of government prosecutors. ${ }^{179}$

- U.S. Attorney Rudolph Giuliani (prior to running for Mayor of New York) initiated numerous highly publicized insider trading cases that resulted in acquittals or reversals or were never brought to trial.

- Many state and county prosecutors' offices retain some or all of the large fines that can be obtained through successful prosecution of environmental crimes or from civil suits seeking "natural resource damages." Thus one can find accounts of district attorneys striving to "build up" damage claims in the style of a plaintiffs personal injury attorney. ${ }^{180}$

Most prosecutors presumably are not overzealous. It is difficult to make any estimate what (undoubtedly small) proportion are, or act that way in at least in some of their cases. In any event, there are a lot of prosecutors; like bad drivers, even a relatively small number can have a disproportionately large effect on the system.

The ethic of zealous advocacy not infrequently seems to draw responsible enforcement attorneys into posture in which "winning" becomes the primary goal; the result is more costly, extortive adversarial legalism. The federal Office of Thrift Supervision is responsible for recovering government-insured losses paid out on behalf of "thrifts" that have failed. "In those instances," a legal scholar has observed, the OTS legal staff "resembles plaintiffs' lawyers in mass disaster cases. The objective is to identify any party with a pocket deep enough to repay the expense of pursuing it . . . [e.g., not only] the officers and directors of the failed association [but also] the accountants, the lawyers, and anyone else who furnished professional services, and the insurers of all of the above."181 Similarly, Church and Nakamura observed that some EPA regional offices took a much more prosecutorial stance than others in seeking remediation of hazardous waste disposal sites under the Superfund statute. In the "prosecutorial" offices, they note: "The informal language of government lawyers is often tough and uncompromising. . . . [Potentially responsible parties] become 'slam dunk' PRPs or 'deep pockets'... . Such views are an outgrowth of the professional training of lawyers, of the ... arguments that they make, and of their inter-

179. Stephen Brill, "U.S. v. Int'l Brotherhood of Teamsters and SEC v Drexel Lambert: When the Government Goes Judge Shopping," in S. Brill, Trial by Jury (New York: American Lawyer Books/Touchstone, 1989).

180. John Privatera, "Using CERCLA's Natural Resource Damage Provision to Focus and Organize a State Environmental Penalty Case: A Personalized Case Study," Nat'l Envtl Enforcement J., March 1992, at 3.

181. Dennis Curtis, "Old Knights and New Champions: Kaye, Scholer, The Office of Thrift Supervision and the Pursuit of the Dollar," 66 S. Cal. L. Rev. 985, 1003 (1993). 
actions with the PRPs themselves."182 The effect, however, is to close doors to cooperative cleanup. "The adversary process," Church and Nakamura came to believe, "with its assumptions about self-seeking behavior, discourages unilateral candor and openness" on the part of the prosecutors. And the result is legal resistance and slower environmental remediation. ${ }^{183}$

\section{LOBBYING TO PRESERVE ADVERSARIAL LEGALISM}

Many lawyer-dominated organizations, from the federal Judicial Council to the ABA, often work for legal reforms that would curtail adversarial legalism. On the other hand, highly organized subgroups of lawyers have been prominent and successful in resisting such reforms, especially those that would make a large dent in the scope and intensity of adversarial legalism. Sometimes they do so for reasons of economic self-interest. Sometimes they do so for idealistic reasons, arguing, with some persuasiveness, that those rules and institutions are bulwarks of justice. The point, in terms of the subject of this article, is that lawyers, operating as political actors, and operating on their own account, have successfully opposed adversarial legalismreducing reforms that serious students of the law believe would be socially desirable.

\section{A. The Civil Justice System Reform Movement}

In April 1993, the governor of New York proposed legislation creating a large fund, supported by a fee on hospital births, to be used to provide compensation for expenses incurred by families whose babies were injured in the course of birth-without the need to bring a lawsuit and prove negligence on the part of the doctor or hospital. ${ }^{184}$ "The bill," cautioned the New York Times, "faces steep opposition from trial lawyers" and "has an uncertain outlook in the Legislature." 185 The trial lawyers' opposition to adversarial legalism-reducing reform is not unusual: they have persistently lobbied to preserve the civil case jury system and to maintain the primacy of the tort law system for compensating accident victims.

182. Church \& Nakamura, Cleaning Up the Mess 27 (cited in note 124).

183. Id.

184. Under the tort law system, governmental officials said, few suits on behalf of infants are successful and those who win in court often have to wait a decade or more to see any money. Under the proposed system, they argued, "instead of a small number of individuals getting very large awards," a much larger number of families would receive moderate compensation. Determinations about eligibility and benefits would be made by a panel consisting of two doctors, a lawyer, a parent of an injured infant, and an expert in developmental disabilities. Sarah Lyall, "A Bill Would Pay for Birth Injuries," N.Y. Times, 21 April 1993, at B12.

185. Id. 
The American tort law and jury system, with its unexplained verdicts, loosely structured law of damages, ${ }^{186}$ and cumbersome methods of decision making, ${ }^{187}$ is an extraordinarily costly, inconsistent, and unpredictable way of compensating accident victims. ${ }^{188}$ So slow, costly, and risky is the system that only a tiny proportion of cases actually are taken to trial. ${ }^{189}$ In England, the civil jury has been phased out (except for libel cases) and the law of damages has been refined by judges. Similarly, early in this century, American states carved one major type of dispute out of the tort law/jury system, enacting laws that would ensure injured workers modest but certain compensation for injury. Employers were made absolutely liable for work-related injuries-without any need to prove they were at fault, without any defense based on contributory negligence. Employers were required to carry workers compensation insurance. Disputes about the extent of accident-related disability were diverted from costly jury trials to administrative tribunals. Workers compensation was to be the exclusive remedy in most cases.

In most European democracies, this "no fault/social insurance" model for compensating accident victims has gradually been extended beyond the workplace. When it appears that certain technologies-highway accidents, pharmaceutical products, medical care-result in a large number of injuries, governments often have responded by enacting specialized compensation and mandatory insurance programs, designed to eliminate costly disputes about fault and to provide victims modest but certain compensation for outof-pocket losses. Tort law damages are limited to economic losses not covered by such social insurance programs, and to legally specified, moderate, noneconomic damages. ${ }^{190}$

186. J. Blumstein, R. Bovberg, \& F. Sloan, "Beyond Tort Reform: Developing Better Tools for Assessing Damages for Personal Injury," 8 Yale J. Reg. 171 (1990).

187. Langbein, 52 U. Chi. L. Rev. (cited in note 6).

188. See R. Bovberg, F. Sloan, \& J. Blumstein, "Valuing Life and Limb in Tort: Scheduling Pain and Suffering," 83 Nw. U.L. Rev. 980 (1989); C. Hammett \& - Relles, "Tort Standards and Jury Decisions," 14 J. Legal Stud. 751 (1985); Jeffrey O'Connell, The Lawsuit Lottery: Only the Lawyers Win (New York: Free Press, 1979); Peter Huber, "Junk Science and the Jury," 1990 U. Chi. Legal F. 273.

189. A. Alschuler, "The Vanishing Civil Jury," 1990 U. Chi. Legal F. 1, 2-3 (1990). Alschuler explains: "the civil trial is on its deathbed, or close to it, because our trial system has become unworkable. The American trial has been bludgeoned by lengthy delays, high attorneys' fees, discovery wars, satellite hearings, judicial settlement conferences, and the world's most extensive collection of cumbersome procedures. Few litigants can afford the cost of either the pretrial journey or the trial itself." Id. at 5-6.

190. In Germany, mandatory worker compensation (industrial accident) insurance coverage was extended to cover students and travel to and from work and school, and thus covers at least one-third, possibly half, of all traffic accident injuries. F. Nutter \& $\mathrm{K}$. Bateman, The U.S. Tort System in the Era of the Global Economy 46 (Schaumburg, Ill.: Alliance of American Insurers, 1989) ("Nutter \& Bateman, U.S. Tort System"). Switzerland extended workers compensation insurance coverage to injuries at home and at play. T. Duffy \& R. Landis, "Workers Compensation in Switzerland," 3 NCCI Digest, March 1988, at 31. In 1961, Germany enacted an "enterprise liability" law for compensating persons harmed by vaccines and added a similar law in 1978 for injuries caused by all pharmaceuticals. Nutter \& Bateman, supra at 44 . Swe$\mathrm{den}$, in addition to making social insurance and medical care the primary recourse for tort 
In the United States, however, the no fault/mandatory insurance model has not been extended, except for a handful of programs such as the 1986 Childhood Vaccine Injury Act and a federal law covering lung damage to coal miners. Workers compensation is still restricted to on-the-job accidents. Indeed, by judicial ruling or legislative enactment, injured workers have been authorized in a widening array of circumstances to circumvent workers compensation programs' exclusive remedy provision and to bring potentially more remunerative tort cases against employers, contractors, and manufacturers of products used in the workplace. Tort claims have driven auto insurance rates so high that many drivers go uninsured. ${ }^{191}$ American medical malpractice and product liability insurance costs are 5 to 10 times as high as insurance rates abroad, ${ }^{192}$ even though most victims of medical malpractice or product injuries recover nothing and many settlements apparently result in much less than full compensation. ${ }^{193}$

There has been no dearth of reform proposals. In the mid-1980s, insurance, medical, and business groups, with substantial support from some legal academics and from municipal governments, mounted a major political campaign to curtail or reform tort litigation. Some 800 civil justice reform bills were introduced in state legislatures in $1986,1,000$ in 1987, and 1,400 in $1988 .{ }^{194}$ The bills sought to modify rules on joint and several liability (so that "deep pockets" only partly responsible for injuries would not be stuck with the whole bill), shorten statutes of limitations, put caps on "pain and suffering" and punitive damage awards, change the collateral source rule (under which tort victims can claim damages even for losses covered by their own insurance), penalize refusals to accept reasonable settlement of-

victims, established special no-fault insurance regimes for motor vehicle injuries, injuries to patients caused by medical procedures, and pharmaceuticals. Carl Oldherz, "Security Insurance, Patient Insurance, Pharmaceutical Insurance in Sweden," 34 Am. J. Comp. L. 637 (1986); Jan Hellner, "Compensation for Personal Injury: The Swedish Alternative," 34 Am. J. Comp. L. 613 (1986).

191. See Stephen Sugarman, "The California Vehicle Injury Plan (VIP): Better Compensation, Fairer Funding, and Greater Safety" (Working Paper, Earl Warren Legal Institute, University of California, Berkeley, 1993).

192. Research on comparative liability insurance costs is sparse and remains anecdotal, but it all points in the same direction. Dow Chemical, whose sales abroad equal those in the United States, said its 1986 legal and insurance expenses in America were five times its overseas costs for comparable coverage, Nutrer \& Bateman, U.S. Tort System 20. Summarizing a 1987 business round table discussion at the Fletcher School at Tufts, Nutter \& Bateman say: "It has been estimated that German producers pay insurance premiums for goods exported to the United States that are four to six times higher than the premiums on exports to other countries." In Canada, physicians in 1986 paid medical malpractice protection fees ranging from $\$ 288$ to $\$ 3,500$ a year depending on their specialties; in the same year, St. Paul Insurance Co., a leading malpractice underwriter, said its typical premiums ranged from $\$ 1,365$ annually for an Arkansas general practitioner to $\$ 106,000$ for a Miami neurosurgeon. Peggy Berkowitz, "In Canada, Different Legal and Popular Views Prevail," Wall St. J., 4 April 1986, at 21.

193. Saks, $140 \mathrm{~Pa}$. L. Rev. (cited in note 8).

194. Nutter \& Bateman, U.S. Tort System 16 (cited in note 189). 
fers, limit contingency fees, and require arbitration or mediation as a prerequisite to a jury trial.

\section{B. ATLA versus Tort Law Reform}

The tort law reform proposals were fiercely opposed by the Association of Trial Lawyers of America (ATLA) and its state-level affiliates. ATLA did not always win. Scores of reform laws were enacted, and they did tend to reduce litigation and award levels. ${ }^{195}$ But ATLA often did win, bottling up the bills in lawyer-dominated legislative committees ${ }^{196}$ or managing to weaken the proposed laws. In at least 17 states, the plaintiffs' bar successfully pursued the battle in the courts, persuading judges to hold tort reform statutes, particularly those imposing caps on damages, unconstitutional under state law. ${ }^{197}$

Throughout the 1980s and early 1990s, ATLA also was a notably wellheeled and formidable lobbying force at the federal level. Political reporters gave ATLA credit for lobbying the Senate to reject an international treaty limiting plaintiffs' damages in air crash cases-even though the American Bar Association favored ratification. "They [ATLA] have a lot more raw political power than the ABA," a former Senate staff member was quoted as saying. ${ }^{198}$ ATLA's lobbying approach, another staffer said, "is characterized by pure political power as much as it is by policy arguments." Using such techniques, ATLA and its 100-person Washington staff played a crucial role in blocking enactment of a federal product liability reform statute designed to standardize liability rules and limit damages. Alarmed by then Vice-President Quayle's civil justice reform ideas-particularly a proposal for a modified "loser pays" rule for counsel fees-ATLA reportedly was a major

195. Patricia Danzon, "The Frequency and Severity of Medical Malpractice Claims: New Evidence," 49 Law 8 Contemp. Probs. 57 (1986).

196. For example, in 1984 the California State Bar supported a bill that would authorize courts to force parties who reject a settlement offer and then do worse at trial to pay the other side's attorneys' fees. The California Trial Lawyers Association opposed the bill, and for two years in a row it died in the ATLA-friendly state senate judiciary committee. Vic Pollard, "Sacramento Scene," Cal. Law., Dec. 1984, at 55.

In New York, a criminal lawyer recently wrote that voir dire "has been distorted by trial lawyers" to the extent that "the average time taken to select a jury is more than twice the time it takes in jurisdictions in which the judge questions potential jurors for bias. ... [S]electing a jury for a trial of even the lowest grade misdemeanor often takes two days"further increasing the pressure on prosecutors to avoid trial by offering concessions in return for a plea. Eliot Spirzer, "Faster Justice in New York," N.Y. Times, 1 March 1993, at A15. The state legislature has failed to act on a proposal calling for judge-controlled voir dire, Spitzer asserts, because of opposition by trial lawyers.

197. Nutter \& Bateman, The U.S. Tort System 16-18. at 1.

198. Steve Nelson, "Trial Lawyers Blaze Aggressive Trail," Legal Times, 14 March 1983, 
contributor to the Clinton campaign, ${ }^{199}$ and Clinton's election seems to have squelched any such federal proposal. ${ }^{200}$ In 1993, ATLA joined with other elements of the bar to lobby Congress to block bold reforms of the pretrial discovery system that had been promulgated by the Supreme Court, based on recommendations of the Federal Judicial Center. ${ }^{201}$ (To the surprise of many, ${ }^{202}$ the reforms squeaked through.).

\section{ATLA versus No-Fault}

The best-documented example of ATLA's activism has been its campaign to block no-fault insurance plans for motor vehicle accident victims. For more than 20 years, research has shown that the tort system only erratically compensates the victims of traffic accidents, often undercompensating the most seriously injured, overcompensating others, and spending more money on litigation costs than on payments that end up in injured plaintiffs' pockets. ${ }^{203}$ Under strong no-fault laws, accident victims would be banned from suing other drivers and would obtain compensation from their own insurers or from a government fund (usually with an exception for catastrophic negligently inflicted injuries).

During the 1965-75 period, no-fault bills were introduced in many state legislatures. They were strongly opposed by ATLA, whose charter declares its dedication to the adversary system and trial by jury. Often, the bills died in lawyer-dominated legislative committees. The no-fault bills that did pass, with few exceptions, were watered down by inclusion of low "thresholds" that preserved the right to bring third party suits for most injuries. ${ }^{204}$

199. L. Gordon Crovitz, "Lawyers Seek Senators as Advocates against Quayle Reforms," Wall St. J., 18 Sept. 1991, at A15. In the 1992 elections, ATLA's political action committee was the nation's fourth largest in total contributions, ranking ahead of the National Education Association and falling just short of the National Association of Realtors, the American Medical Association, and the Teamsters. "Who Gave the Most," N.Y. Times, 11 June 1993, at A12.

200. The "American rule" provides that each party in civil cases, win or lose, is responsible for paying her own counsel fees. Under this rule, as compared to a rule whereby the loser pays the winner's counsel fees-as in England and in most European countries-it is less risky for plaintiffs to file and pursue long-shot cases, and more tempting for defendants to discourage just claims by mounting costly, time-consuming legal defenses. There are reasonable arguments to be made on both sides of the counsel fee issue. The relevant point here is that organized American lawyers' groups helped perpetuate the rule that tends to encourage, not reduce, adversarial legalism.

201. A. Sanborn, "Derailing the Rules," Nat'l L.J., 24 May 1993; R. Schmitt, "Lawyers United against Plan to Speed Suits," Wall St. J., 8 June 1993, at B7. 1993.

202. R. Schmitt, "Plan to Cut Civil Litigation Costs Blocked," Wall St. J., 15 Sept.

203. Rabin, 25 San Diego L. Rev. at 24, 34 (cited in note 172).

204. U.S. Department of Transportation, Compensating Auto Accident Victims: A FollowUp Report on No-Fault Auto Insurance Experiences (Washington, D.C.: U.S. Department of 
When a federal no-fault bill was introduced in the Senate in 1971, it was supported by broadly representative labor and consumer groups as well as by large stock insurance companies. ${ }^{205}$ It was vigorously attacked, however, by ATLA. ATLA raised its dues, hired lobbyists and public relations firms, created a political action committee that used its funds to reward congressional foes and target supporters of no-fault, and mobilized its members to bombard members of Congress with anti-no-fault telegrams. Throughout the 1970s, in session after session of Congress, the Senate Commerce Committee voted to support the Bill, but ATLA lobbyists managed to prevent it from being brought to a vote, often succeeding it getting referred to the lawyer-dominated Judiciary Committee. ${ }^{206}$

\section{Asbestos}

The American method of compensating victims of exposure to asbestos epitomizes the adversarial legalistic method of dealing with social problems. Imaginative lawyers exposed industry's failure to adequately protect workers. Innovative judges empowered diseased workers to circumvent the workers compensation system and file tort suits against asbestos manufacturers. The resulting barrage of lawsuits conveyed a powerful deterrent message to other industries. But even observers supportive of product liability litigation acknowledge that "[a]sbestos litigation . . . has come close to crippling the entire litigation capabilities of the American judiciary."207 The volume of cases is enormous; they entail complex issues concerning which employers and insurance companies are responsible for occupational exposures that occurred decades earlier. The potential damages are far larger that the net worth of the asbestos industry. RAND Institute of Civil Justice studies have indicated that close to $75 \%$ of insurance company expenditures in asbestos cases have ended up in the pockets of lawyers and experts, as opposed to asbestos victims and their families. It is hard to imagine a more costly and inequitable way of dealing with tragedy. ${ }^{208}$

Transportation, 1985); David Foppert, "Does No-Fault Stack up?" in Best's Review: PropertyCasualty Insurance Edition (Oldwick, N.\}.: Best Co., 1992).

205. The Hart-Magnusen Bill was supported by the Consumer Federation of America, the Teamsters, the United Auto Workers, the AFL-CIO, and the American Association of Retired Persons. One prominent consumer advocate who did not support the bill was Ralph Nader, who is widely assumed to receive a good deal of financial support from ATLA. P. Heymann \& L. Liebman, 'No Fault, No Fee: The Legal Profession and Federal No-Fault Insurance Legislation" in Heymann \& Liebman, eds., The Social Responsibilities of Lauyers (Westbury, N.Y.: Foundation Press, 1988).

206. Id. at 325-30.

207. J. Henderson \& A. Twerski, "Stargazing: The Future of American Products Liability Law," 66 N.Y.U.L. Rev. 1332, 1336 (1991).

208. Peter Schuck, "The Worst Should Go First: Deferral Registries in Asbestos Litigation," 15 Harv. J.L. \& Pub. Pol'y 541, 553-68 (1992); Lester Brickman, "The Asbestos Litigation Crisis: Is There a Need for an Administrative Alternative?" 13 Cardozo L. Rev. 1819 
As the dimensions of the asbestos problem became apparent, proposals were made to create a federally administered fund to compensate victims, analogous to that created for coal miners suffering from black lung disease, without the need for costly civil litigation. It never was enacted. ATLA opposed the idea-although it is not clear whether the failure to enact such a plan is more attributable to ATLA's opposition or to the lack of cohesion among proponents, unable to agree on plans for funding it.

\section{Workers Compensațion}

In most European worker compensation plans, disputes about degrees of permanent disability are resolved by panels of government physicians and other experts. In the United States, it is common for each side to hire its own doctors, selected for propensity to favor either employer or employee respectively. ${ }^{209}$ Dissatisfaction with workers compensation is rife, not only among employers but among injured employees and claimants attorneys. Yet claimants attorneys' associations routinely have lobbied against legislative reform proposals that would replace "dueling doctors" with government-appointed doctors to determine the extent of disability, ${ }^{210}$ as well as against other litigation-inhibiting reforms. Similarly, it is hard to find a more inefficient and costly system than the Federal Employers' Liability Act (FELA), which excludes injured railroad workers from workers compensation systems, requiring them to sue their employers for damages, before a jury, and prove fault. Awards are high for some, driving total costs and lawyer bills high, but many injured workers get nothing. Year after year, attempts to reform FELA have been killed in Congress, often by Senator Metzenbaum, a former FELA lawyer who is heavily lobbied by (and has received large political contributions from) the FELA bar. ${ }^{211}$

(1992); James S. Kakalik et al., Costs of Asbestos Litigation (Santa Monica, CA: RAND Institute for Civil Justice, 1983).

209. One study of permanent disability claims indicated that in Maryland, New Jersey, and some categories of cases in Wisconsin, "dueling adversary experts" were employed in 63\%, $79 \%$, and $63 \%$ of cases, respectively, and "friction costs" added up to $38 \%, 46 \%$, and $42 \%$ of the total disability payments awarded (WCRI, Reducing Litigation: Evidence from Wisconsin (Cambridge, Mass.: Workers Comp. Research Institute, 1988).

210. Another demonstrated method for drastically reducing adversarial legalism is the "final-offer adjudication" rule adopted for some categories of cases in Wisconsin. The adjudicator is pledged not to "split the difference" but to adopt the percentage of disability found by either the employee's or the employer's physician; in consequence, extremely divergent assessments are uncommon. Together with a more aggressive staff role in making initial determinations, this Wisconsin plan has resulted in enormous reductions in attorney use and "friction costs." Id. One has to wonder what role claimants' attorneys have played in preventing diffusion of this reform.

211. See J. Birnbaum, "Political Contributions of Narrow-Focus Groups Seen by Some as Growing Campaign Funds Issue," Wall St. J., 22 Dec. 1989, at A8. 


\section{CONCLUSION}

Lawyers are not the only or even the primary source of American adversarial legalism. Far more important are the preferences of their clients and of the political interest groups and leaders who seek to shape public policy. Adversarial legalism is also the product of a populist political culture, inclined to trust courts rather than "big business" and "big government" and reluctant to finance European-style social insurance programs that could displace much civil litigation. Adversarial legalism is also stimulated by a constitutional tradition that has limited central bureaucratic government and encouraged litigation as a mode of checking governmental arbitrariness.

But as our necessary selective tour d'horizon of the legal system indicated, there is abundant evidence that American lawyers, or at least significant segments of the profession, play a substantial contributory causal role. Lawyers, law professors, and judges generate a legal culture that supports adversarial legalism as an essential aspect of governance. Organized groups of lawyers systematically lobby courts and legislatures to extend the realm of adversarial legalism and to block reforms that would reduce it. Lawyers have created and defended an ethic of zealous advocacy that in the hands of some practitioners-but not merely a few-legitimates superaggressive legal contestation.

Moreover, although hard-and-fast measures are elusive, lawyers' adversarial legalism-promoting activities and ideas have increased in recent decades. To be sure, throughout its history the American legal profession often has struggled to preserve a large and autonomous policy-making and dispute-resolving role for courts-thereby enhancing lawyers' opportunities for economic gain and political influence. ${ }^{212}$ But the legal profession also has changed in recent decades, magnifying its contribution to adversarial legalism.

First, there are many more institutional niches and spheres of law that sustain the kinds of lawyers' activities which promote adversarial legalism. The legal profession has become much larger and richer. Law penetrates far more deeply into economic and social life. Hence there are more lawyers with both the capacity and the opportunity to engage in the aggressive lawyering examined earlier.

For there is an essential truth in the lawyers-as-consequence thesis: the advent of a distinctively American activist government-one that relies on decentralized governmental and economic institutions, legalistic regulation,

212. See Richard Ellis, The Jeffersomian Crisis: Courts and Politics in the Young Republic 111-22, 157-83 (New York: W. W. Norton, 1971); Arnold Paul, The Conservative Crisis and the Rule of Law: Attitudes of Bar and Bench, 1887-1985 (Ithaca, N.Y.: Cornell University Press, 1960); Benjamin Twiss, Lawyets and the Constitution: How Laissez-Faire Came to the Supreme Court (Princeton, N.J.: Princeton University Press, 1942); Shamir, 27 Law \& Soc'y Rev. (cited in note 22). 
and adversarial legal challenge to help attain the ideals of "total justice"vastly increased the demand for lawyers. There are more of them, working in more and larger organizations. Their activities are better funded. There is far more law and hence a wider array of policy fields for lawyers to work in. Hence those lawyers who either believe in or profit from adversarial legalism have greater opportunities to act.

Thus, as recently as 30 years ago, there were few toxic tort cases, hostile corporate takeovers, technology-forcing environmental regulations, or class actions involving employment discrimination-all of which include the kinds of high-stakes legal actions that warrant huge investments in aggressive and creative lawyering. Thirty years ago, the organizational landscape for lawyering, and hence for aggressive lawyering as well, was far more spare. There were few public interest law firms and specialized legal advocacy groups, few governmentally funded public defenders' offices. There were no environmental agencies with large legal counsels' offices, no computer-and-FAX-coordinated networks of product liability lawyers. Corporate law firms, U.S. Attorneys' and state attorney generals' offices were far smaller. So was the legal professoriat. No bar association could come close to matching the fund-raising and lobbying capacity of contemporary trial lawyers' associations.

In sum, the lawyers-as-secondary-cause thesis "works" because the political changes and governmental structures emphasized by the lawyers-asconsequence thesis greatly enhanced the demand for lawyering.

Second, perhaps the most important aspect of the lawyers-as-secondary-cause thesis is that American lawyers have created a legal culture that legitimates adversarial legalism and efforts to extend it. Legal ideas, generated by law professors and activist lawyers, help shape legislation and judicial policy decisions that rely on adversarial legalism for implementation.

But in this respect, too, legal culture is at least as much consequence as cause. For in the last two generations the center of gravity of elite (or lawyers') legal culture has shifted. It became more supportive of an instrumental, "social engineering," or even political vision of law and the judicial role. It became more egalitarian, stressing expanded access to courts and an ever growing panoply of individual and group rights. This shift did not occur merely via debate in law reviews. Lawyers' "legal culture" changed in response to political upheavals that led to huge increases in governmental activism. Government sought to transform society, and law professors and activist lawyers began to address the same agenda. ${ }^{213}$ In short, lawyers' legal culture was reshaped by a turbulent, encompassing political culture that increasingly called upon the legal order to meet its hopes for "total justice."214

213. See Bruce Ackerman, Reconstructing American Law (Cambridge, Mass.: Harvard University Press, 1984).

214. See pp. MS. 9-11 000-00 supra. 
How important in the whole scheme of things, then, are the lawyers' own ideas and aggressive practices? What if all the lawyers-or at least those who consciously work to extend and preserve adversarial legalism, or engage in superaggressive litigation-were suddenly banished to a reservation in central Nevada? It is hard to believe that the resulting change in the legal order would be truly massive in the long run. The social divisions, economic conflicts, political fragmentation, and popular beliefs that generate adversarial legalism surely would not disappear.

On the other hand, suppose American lawyers-not just a few but most of them-reconfigured legal ethics to discourage superaggressive litigation; and argued that social insurance was preferable to tort law for compensating injury; and insisted that judges should urge legislatures to reform the laws rather than doing it themselves; and lobbied for the creation of cheaper, less adversarial dispute-resolution forums; and fostered administrative law and conceptions of due process that sought to improve rather than subvert administrative authority? After all, that is not so different from the stance taken by the legal profession in other rich democracies. If the bulk of the legal profession did these things, it almost certainly would have some effect-probably a considerable effect-on the level of adversarial legalism. For what lawyers think and say, the legal culture they generate and the behaviors they exhibit, surely influence what clients, interest groups, legislators, journalists, and the general public think appropriate to demand of the legal order.

Indeed, perhaps it is ultimately fruitless to try to tease out the relative causal importance of lawyers' legal culture and practices. American lawyers' legal culture reflects a surrounding political culture that also mistrusts authority, values individual liberty and the right to challenge government in court, treasures the jury system, and prefers a politically responsive to a professionalized, bureaucratic judiciary. Conversely, lawyers' distillations of those broader sentiments into a more focused ideology of adversarial legalism have worked themselves into the warp and woof of legislative hearings, the drafting of laws, administrative and business procedures, the news media, and the dramas shown on television and in movie theaters. The causal diagrams presented earlier should in truth include feedback loops among all the boxes.

In the 1960s, the comedian Lenny Bruce used to say that in New York City, even the Gentiles were Jewish. In the law-saturated United States of today, he might say that even the laymen are lawyers. Or at least every politician, governmental official, and corporate executive, law-trained or not, thinks like a lawyer to a considerable extent. So if American lawyers are not the only force working to recreate adversarial legalism, it may be partly because they have trained their fellow citizens to do it too. 